\title{
Bacterial Translocation
}

\author{
Reiner WIEST* \\ Department of Internal Medicine I, University Hospital Regensburg, Germany \\ Received for publication, December 20, 2004
}

\begin{abstract}
This lecture first highlights the methods available to detect bacterial translocation (BT) as well as shortcomings related to those. Secondly, mechanisms involved in the process of BT with special focus on intestinal flora, gut barrier dysfunction and the role of immune defence mechanisms are discussed. Thirdly, the potentially huge clinical relevance of BT is reviewed. BT is the key to our understanding of spontaneous bacterial peritonitis in liver cirrhosis, the multiorgan failure syndrom induced by hemorrhagic shock, burns or sepsis and is involved in a multitude of diverse gastrointestinal lesions. Therefore, BT may represent a common and so far inadequately recognized trigger for a multitude of complications known for long in various clinical entities. Finally, the focus will be to discuss advances in therapeutic approaches in preventing BT and associated potential complications. There is much evidence linking diet with the maintenance of intestinal integrity and multiple enteral manoveures have been tested. Particularly promising is the avenue of using probiotics known to exert many effects and to protect the gut from BT. Various other therapeutic approaches include binding/neutralizing of endotoxins, hyperbaric oxygen, prostaglandins, antioxidans etc. A more general attempt to reduce the presumed risk of BT is selective gut decontamination (SGD). In summary, the concept of BT contributing to morbidity is of extraordinary importance and its detailed investigation will eventually open an avenue for preventive measures against infectious complications.
\end{abstract}

Key words: bacterial translocation; mechanisms; immunity; terapy

\section{INTRODUCTION}

The passage of large particles through the intestinal barrier, initially called perseption, was recognized as early as 1844 by Herbst (131). Volkheimer and Schulz reported 1968 that intact strarch particles could be transported across the intestine of healthy normal human subjects (297). The term bacterial translocation (BT) has been coined by Berg and Garlington describing "the passage of viable enteric bacteria from the intestinal lumen through the epithelial mucosa into the lamina propria and then into mesenteric lymph nodes (MLN's) and possibly other organs" (26). This definition has later been refined by including all microbial translocation, defined as the passage of both viable and non-viable microbes and microbial products such as endotoxin across an even anatomically intact intestinal barrier.

\section{MATERIALS AND METHODS}

The endpoint most commonly used to prove and quantitate BT is by enumerating culturable organisms in the MLN's. However, data using radioactively labelled bacteria indicate that this technique vastly underestimates the extend of translocation since, most

*Corresponding author. Mailing address: Department of Interna Medicine I, University Hospital Regensburg, Germany. Phone: +49-941944-7001. Fax: +49-941-944-7073.

E-mail: reiner.wiest@klinik.uni-regensburg.de microbes breaching the epithelial barrier are killed. In fact, less than $0.1 \%$ of radioactive labeled Escherichia coli localizing in MLN's was associated with viable bacteria (6). This indicates that increases in BT demonstrated by increases in colony forming units (CFU's) in MLN's are predominantly due to a decrease in killing rather than an increase in transepithelial penetration. As indirect marker any detection of intestinal bacteria in culture of portal or peripheral blood also evidences BT. Similarly, the discovery of endotoxin in peripheral blood suggests BT. However, in animal studies bacteria are rarely cultured from peripheral blood a finding most likely due to the defense mechanisms provided by liver and lungs eliminating microorganisms by tissue macrophages.

Recently, PCR-methods have been introduced for detection of microbial DNA in blood demonstrating a higher sensitivity than blood cultures for assessment of BT from the intestine (145). Over the last couple of years thus, several approaches have been published for the PCR-based detection of bacterial DNA (bactDNA) used as sort of surrogate marker for BT also in humans. However, some critical notes have to be considered when interpreting such data. It should be noted that the often used term "universal PCR" is misleading somehow since no sections within the $16 \mathrm{~S}$ rDNA sequences of eubacteria are perfectly conserved among all known species. Primer design is always conducted by best compromises, 
and the fact that some species may escape from efficient amplification and are therefore underrepresented in the final PCR reaction mixture, is reflected by the more common term "broad-range PCR" (65). Broad-range eubacterial PCR however, is highly sensitive, and even minor contamination with DNA of any other bacterial species may result in false-positive results. In fact, a well-known problem in detecting small amounts of bactDNA is the possibility of exogenous bactDNA contamination events in the course of obtaining and/or processing the corresponding sample material as well as endogenous contamination due to the presence of residual bactDNA in the various reaction components. Most importantly, analytical sensitivity of the current technology is heavily restricted by bactDNA contamination of PCR reagents and DNA extraction kits. For example, in an earlier study on blood samples from patients with bacteremia, the superior sensitivity of eubacterial PCR assays was instantly called into question because the rate of false-positive PCR findings was as high as $40 \%$ (272). In principle, reliable detection of very small numbers of bactDNA in clinical samples requires the elimination of any contaminating DNA to avoid false-positive results and to achieve an adequate signal to noise ratio of the respective assay concept (151). In routine practice, however, these promising options are consistently vitiated by the fact that all of the various decontamination protocols are reducing the overall analytical sensitivity of the PCR assay to a certain extent (61). Nonetheless, applying an eubacterial PCR assay and taking efficient precautions to prevent exogenous contamination also in healthy volunteers or patients with chronic fatigue syndrome a variety of bacterial species could be identified in plasma samples $(130,204,296)$. Since no independent method of detecting low amounts of bactDNA in culture-negative samples is available, it is not possible to tell with absolute certainty whether positive PCR results in the presence of negative culture results are true- or falsepositives. As in many other fields of molecular microbiology the qualitative or quantitative determination of bactDNA by PCR or comparable methodology for nucleic acid amplification is an promising and fascinating tool for the detection of traces of bactDNA in normally sterile body fluids or biopsies. The degree of analytical sensitivity, however, which is at least theoretically required for investigating and tracing BT events approaches the intrinsic limitations of current PCR technology. It is simply not possible to distinguish between low copy numbers of bactDNA in clinical specimens and the bactDNA that contaminates the reagents used for specimen processing and PCR amplification. With the use of culture-independent and highly-sensitive molecular methods for the detection of bacterial DNA, there is growing evidence of "microbial contamination" within anatomically priviledged compartments of the human body that have previously been considered sterile most of the time. Since a number of reliable studies have clearly demonstrated the circulation of bactDNA in the blood of healthy individuals $(130,204,296)$ the solely detection of bactDNA should no longer be considered as a diagnostic marker for infection or disease. As a consequence, aspects of target DNA quantitation and the use of species-specific assays are of increasing importance to establish etiologic diagnoses by investigating the relationships between circulating bactDNA and disease.

Moreover, intestinal permeability can be assessed by a variety of techniques (for review see (34)). Initially, single test substances (various polymers of polyethylene glycol [PEG] or nondegraded radiolabeled chelates such as $\mathrm{Cr}^{51}$-labeled ethylenediaminetetraacetic acid $\left[\mathrm{Cr}^{51}\right.$ EDTA] or $99 \mathrm{~m}$ Tc-deitehylenetriaminopentaacetate [99mTc-DTPA]) and calculation of plasma-to-intestinal luminal clearence of these tracer molecules was used. However, results were influenced by a change in any of the premucosal or postmucosal factors apart from intestinal permeabiltiy itself. This led to the principle of differential urinary excretion of two different orally administred nonmetabolizable sugars, which provides a specific index of intestinal permeability. One probe typically consists of a relatively small molecule, which permeates moderately well through even normal mucosa. A second probe consists of a larger molecule, which minimally permeates a normal mucosa. By measuring the concentration of both probes in urine and thus, monitoring differential absorption, confounding effects are somewhat factored out. Ideally such permeability probes have to be nontoxic, nondegradable, should exhibit first-order-kinetics of permeation and lack natural presence in urine. Finally urinary excretion at best should be complete following instillation and measurement of the probe has to be sensitive and accurate as well as easy. Most commonly used are a monosaccharide and a disaccharide together, such as mannitol and lactulose, known to pass transcellularly or paracellularly, respectively, through the epithelium. Unfortunately, a multitude of various factors affect urinary excretion of orally administered test substances such as gastric/intestinal dilution, intestinal transit time, bacterial degradation (e.g. in case of bacterial overgrowth), alterations in intestinal blood flow, renal 
function and even timing and completeness of urinary collection. Moreover, attention has to be paid on osmolarity of the test solution potentially affecting paracellular permeability as well as on water-/ lipidsolubility influencing the predominant anatomic pathway the probe is using for transepithelial passage. All these shortcomings need to be considered when interpreting any results obtained particularly in disease processes known to affect any of the stated parameters.

Due to the inherent limitations of in-vivo studies other approaches to delineate BT in more detail have been developed in experimental settings using either pure enterocyte cell culture grown to confluence on semipermeable membranes or segments of intestine being stripped from seromuscular coat leaving the mucosal layer. Transepethial electrical resistance (TEER) can be assessed in such preparations (usually using an ohmmeter) reflecting permeability and correlating with the tightness of epithelial cell-occluding junctions. Another way to estimate permeability is to determine by fluorescent or radioactive probes being applied to the apical compartment of those preparations and calculated as flux of per unit membrane/mucosal layer. Finally, a new modalitiy to investigate mechanisms of BT uses green-fluorescence-(GFP)marked bacteria $(119,176,277)$. GFP was first isolated from the jellyfish Aequorea aequorea being responsible for autofluorescence in presence of oxygen. Due to its small size, formidable stability and ease to use it is utilized increasingly to visualize bacteria. GFP-marked bacteria can easily be sensed and detected by fluorescence microscopy. Moreover, bacteria expressing plasmid-encoded GFP have been shown to do so without selective pressure for a substantial time and for up to 100 doublings and even after the cell has become nonproliferative (19). Using GFP-transfected E.coli Samel et al. could visualize the process of BT across the gut wall into the submucosa and muscularis propria in a model of small bowel obstruction by intravital microscopy (256). Moreover, intestinal ischemia induced by selective clamping of the supplying mesenteric vessel drastically accelareted this translocation of GFP-marked E.coli and two hours after intraluminal administration GFP-E.coli were also visible in frozen sections of mesentery, liver and spleen demonstrating bacterial spreading. This promising tool will also ease investigations to unravel the major site of BT as well as the exact anatomic route of translocation.

\section{RESULTS AND REVIEWS}

Mechanisms of BT

The gastrointestinal tract is unique as it represents the largest surface area of the body and on top is constantly exposed to microorganisms. Therefore, it is unlikely that this microbial ecosystem evolved by chance and likewise unlikely that the mutual co-operation with the host is achieved without clearly defined lines of communication. In general proposed mechanisms promoting $\mathrm{BT}$ include a) changes in intestinal microflora, b) mucosal barrier failure and c) defects in host immunity (Fig. 1). These determinants of BT should not be viewed as individual separate etiolopathological factors but rather as interrelated aspects influencing each other. In fact, a concerted synergistic interplay of multiple defense mechanisms has been developed during coevolution of humans and bacteria ensuring an adaptive commensal relationship where neither partner is harmed.

\section{Intestinal microflora}

This review does not intend to summarize microbioloical aspects however, important facts related to the issue of BT are as follows. It has been commented that $>90 \%$ of the total cells of a healthy human are actually bacterial cells. Overall bacteria account for up to $50 \%$ of the volume the human colon contains and the total weight of microflora in the human gut has been estimated to be about $1 \mathrm{~kg}$. Most of these are commensals that coexist peacefully with their host and remain harmless provided that they do not stray beyond the gut lumen. Composition of the microbial flora differs widely along the gastrointestinal tract and from the lumen to the mucosa as well as between individuals. Though whereas the upper GI tract is usually sparsely populated microbial density increases towards the ileum and reaches $10^{12-14}$ / gram in the colon. It is important to stress the qualitative and quantitative differences between luminal bacteria and bacteria attached to the mucosal surface since, only the latter are prone to translocate. As for individual heterogeneity twin studies clearly demonstrated a large diversity in microorganisms populating homozgotic twins $(326,327)$. Host environment factors regulate not only the composition of the intestinal microflora but also bacterial virulence factors (121).

The bacteria that seem to translocate most readily are those usually classified as facultative intracellular pathogens - i.e. those that are able to survive outside the white blood cell but are also able to resist phagocytic killing. Classic examples are Salmonella species and 

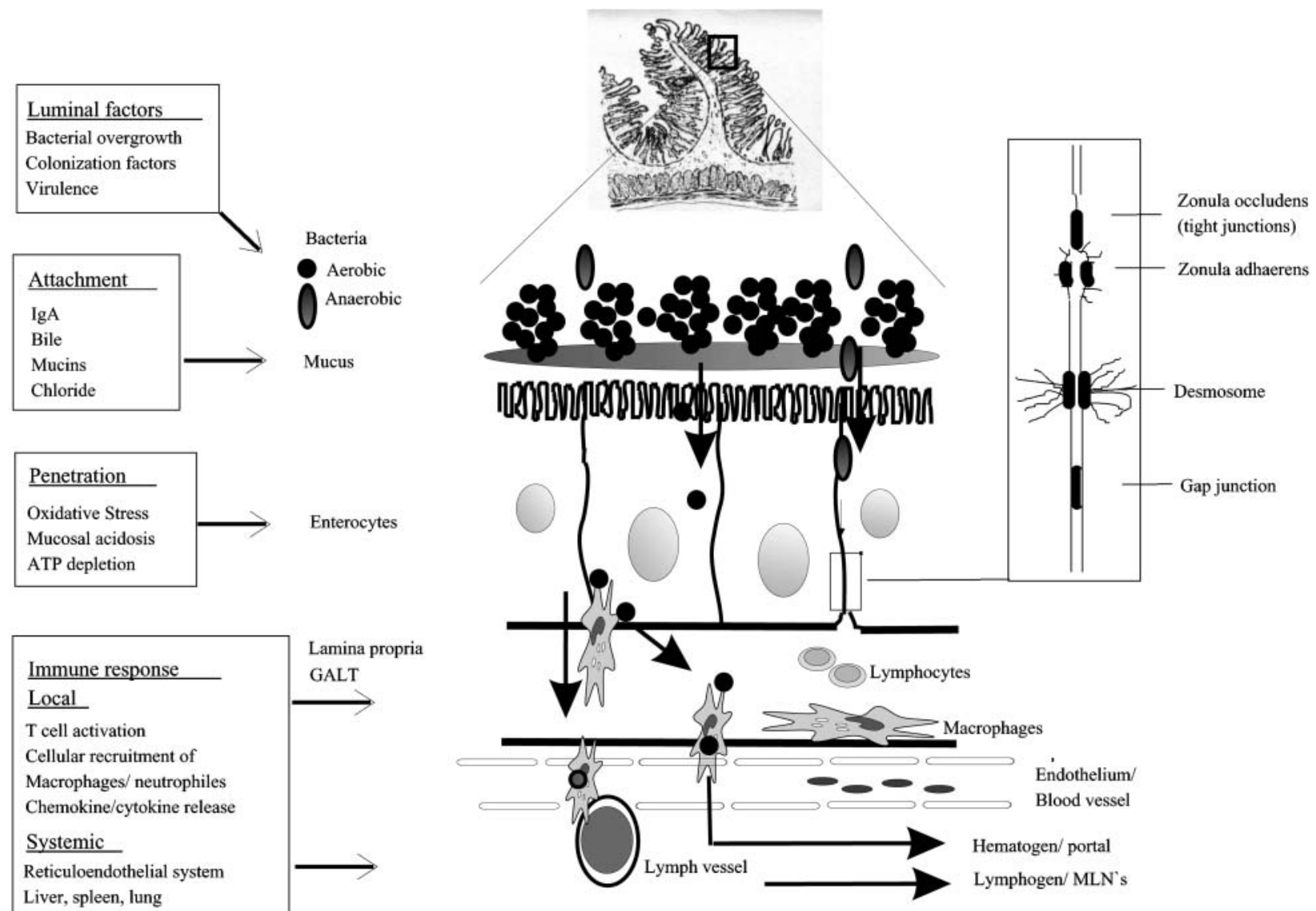

Fig. 1. Mechanisms of BT. Factors involved in the process of BT include changes in the intestinal microflora, alterations in mechanisms preventing attachment and penetration of bacteria and finally, local and systemic immune responses aiming to kill bacteria that have translocated.

Listeria monocytogenes which translocate readily after oral inoculation into experimental animals that have previously undergone intestinal antibiotic decontamination and subsequent intestinal overgrowth of an antibiotic-resistant translocating organism. In contrast, normal enteric species are easily killed after phagocytosis, surviving only under circumstances that impair host defenses. Of the more than 500 species of normal intestinal bacteria relatively few have been shown to translocate with any frequency. Steffen et al. investigated whether the various organisms in the indigenous gastrointestinal flora translocate at the same rate or whether certain species are especially adept in translocating form the gut (282). Particularly aerobic and facultative anaerobic gram-negative bacteria were found to translocate in high numbers to the MLN's of monoassociated gnotobiotic mice. In detail, the few intestinal bacteria that most frequently translocate include E. coli, K. pneumoniae, other Enterobacteraceae,
P. aeruginosa, Enterococci and other Streptococci (307). Curiously, these species are those most frequently associated with complicating infections in severly ill, hospitalized and particularly cirrhotic patients.

Recently, it has been evidenced that also the strain of bacteria is important for its capacity to translocate. For instance, special strains of E.coli have been reported to be more efficient translocators as compared to others $(146,164,198)$. One explanation could be that several strains of $E$. coli show better adherence and attachment to the mucus-epithelium layer than non-pathogenic bacteria (23). In general, adhesins have been shown to be associated with fimbriae of enteric bacilli. This fimbriated surface structure (so called colonization factor) of e.g. E. coli has been evidenced in volunteers to be required for intestinal multiplication, clinical illness and humoral antibody production (258). Moreover, differences in virulence among strains has been suggested in respect to resistance against host defence 
mechanims allowing survival and spreading of those bacteria more efficiently than others $(8,87)$.

Although intestinal anaerobic bacteria outnumber aerobic bacteria by $100: 1$ to $1000: 1$ anaerobes can very rarely be induced to translocate (282). The reason for this is still unclear. Translocation of anaerobic bacteria has been reported only in extreme circumstances such as athymic (213), lethally irradiated (41) or severely burned rodents (307). In nearly all these conditions, breaks in enteric integrity are found, and anaerobic bacteria appear to translocate in direct proportion to the degree of tissue damage. Thus, in contrast to aerobic gram-negative bacilli that translocate easily and even across a histologically intact intestinal epithelium $(282,304,306$, 307) anaerobic bacteria seem to translocate in situations in which the intestinal tract is mechanically damaged. Moreover, it is well-known that anaerobic bacteria as a carpet on the mucosal surface limit colonization and overgrowth of other potentially invasive microbes. Thereby, anaerobic bacteria rather help to confine potential pathogenic bacteria to the intestinal lumen and support maintaining the stability of the intestinal flora than to promote BT (304). In fact, selective elimination of anaerobic bacteria facilitates intestinal overgrowth and translocation of facultative bacteria (304). In deed, most evidence linking translocation of normal enteric flora and intestinal overgrowth has been derived from models of gnotobiotic animals or selectivedecontaminated animals given a correponding antibioticresistant organism. In these animals extremely high intestinal population levels are achieved associated with translocation to extraintestinal sites. This has lead to the conclusion of bacterial overgrowth being one of the main factors promoting BT. In fact, a direct relationship between the numbers of a bacterial strain populating a segment of the intestine and the numbers of viable bacteria of this strain present in MLN has been demonstrated in mice (283). In this context, it is important to differentiate two distinct intestinal microfloras. The first, is found within the lumen of the gut, and the second is associated with the mucosal surface. Although the levels of luminal bacteria clearly are important in the development of infections in situations of bowel injury or perforation, the levels of mucosally adherent bacteria are most likely to be more important in the development of BT (37). Bacterial overgrowth in general is defined as a bacterial count $>$ $10^{5}$ colony forming units $/ \mathrm{ml}$ in fluid obtained from the intestine during duodenal intubation. Factors promoting bacterial overgrowth include reduced gastric acidity (e.g. due to use of antiacids) but predominantly gastrointestinal dysmotility. In fact, disruption of the migration motor complex by morphine results in an increase of bacterial growth and associates with BT to MLN (203). Interestingly, bacterial overgrowth per se has been proposed to result in selective loss of brush border alkaline phosphatase activity (20) and to modulate systemic cytokine response to e.g. hemorrhagic shock leading to marked increases in plasma TNF and IL-6 $(122,123)$.

\section{Mucosal barrier dysfunction and site of translocation}

Secretory mucosal barrier: Preventive measures against attachment of microbes to the epithelial surface known to be the first important step in epithelial penetration include mucus, chloride, gastric acid, pancreatic enzymes, bile and a diversity of antimicrobial peptides. Mucins, secreted by epithelial goblet cells in copious amounts ( $3 \mathrm{~L} /$ day), create a layer of membraneanchored negatively charged glycoproteins forming the so-called filamentous brush border glycocalyx (17). This thick $(400-500 \mathrm{~nm})$ layer serves 1$)$ as a diffusion barrier that prevents direct contact of most macromolecules, particles and bacteria with the microvillus membrane but is easily accessible to digested nutrients 2 ) acts as a lubricant to reduce physical abrasion of the mucosa and participates in the protection of the mucosa from damage induced by acid and other luminal toxins and 3) serves as a highly degradative microenvironment owing to the entrapped pancreatic encymes and membrane-bound hydrolytic encymes. Additional trefoil factors concomitantly secreted by mucin secreting epithelial cells participate in stabilisation of the mucous gel protection from deleterious agents and promote mucosal repair at sites of mucosal injury (316). Active chloride transport by epithelial cells promotes intraluminal fluid flux that washes away harmful agents. Mucosal secretions are rich in IgA antibodies that effectively bind and aggregate bacteria preventing mucosal adherence and colonization (so called immune exclusion) (279). In fact, IgA accounts for more than $70 \%$ of total body immunoglobulin production ( $>5 \mathrm{~g} /$ day and $>\mathrm{IgG}$ and IgM combined). However, one has to distinguish serum and secretory IgA since mucosal surfaces are neither source nor destination of serum IgA. Secretory mucosal IgA serves not only as guardian from microbial entry but also neutralizes toxins and infectious organisms and even may actively transport IgA-bound antigens/microbes as a sort of "sump pump" from the lamina propria back to the lumen. IgA is secreted by plasma cells derived from B cells that "home" to the lamina propria where they mature. IgA is transported across the epithelial border by 
receptor-mediated endocytosis initiated by a secretory component, which is the extracellular domain of a 110000 molecular weight transmembrane glycoprotein. Bile inhibits bacterial overgrowth, has a trophic effect on the intestinal mucosa (162) decreases epithelial internalization of enteric bacteria (302), exerts detergent actions with anti-adherence effects and binds and neutralizes endotoxins $(33,293)$. Moreover, the absence of bile in the intestinal tract has been shown to affect homing and distribution of $\mathrm{T}$ lymphocytes in the GALT decreasing the numbers of CD $4+$ and $C D 8+T$ lymphocytes and mucosal addressin cell adhesion molecule-1 (MAdCAM-1) expressing cells in the lamina propria (257). Finally, bilirubin has been shown to impair bactericidial activity of neutrophils attenuating bacterial clearance mechanisms (16).

Several antimicrobial peptides and proteins have been identified and thought to function as natural antibiotics due to their ability to kill a variety of microbes under laboratory conditions (323). $\alpha$-defensins are released by a cluster of cells located at the bottom of each intestinal crypt, so called Paneth cells, in response to bacteria and lipopolysaccharides $(18,209)$. Paneth cells are normally restricted to the small intestine and are found most abundantly in jejunum and ileum, where they may play an important role in maintaining the relative sterility of the lumen. In contrast to enteric $\alpha$-defensins, human $\beta$ defensin 1 (HBD1) appears to be expressed by most epithelial cells of the small and large intestine (205). Evidence for the functional importance of defensins comes from studies in mice lacking matrilysin, an encyme that activates several mouse intestinal defensins, presenting with impaired resistance to intestinal infections, e.g. defect in clearance of orogastrically administrated gram-negative bacteria (312). Human Paneth cells code for two $\alpha$-defensins, HD-5 and -6 . Genetic transplant of human defensin 5 (HD-5) into mice is associated with greater antibacterial activity against E.coli as well as improved resistance to intestinal infections with e.g. Salmonella typhimurium (254). The peptide also remains active even after partial proteolysis, an indication of its potential to function within the environment of the intestinal lumen (228). Other larger proteins such as lysozyme (181) and secretory phospholipase A2 (126) are likewise released by Paneth cells and may also be involved in local defense against commensal bacteria. Thus strategically located just below the stem cell zone, Paneth cells detect bacteria that occupy the crypt lumen and secrete defensins in order to kill them and inhibit colonization of the crypt lumen. By this the microenvironement is protected from bacterial overgrowth and bacterial infection and stem cell replication can proceed continously to maintain mucosal integrity. In chronic inflammatory bowel disease HD-5 and-6 occurs also in the colonic epithelium (64) and has been speculated to assisst in the killing of luminal microbes to prevent invasion across the damaged mucosal surface. As for HBD1, in vitro testing evidenced antimicrobial activities against gram-negative bacteria including E. coli and Pseudomonas aeruginosa but limited acitivity against gram-positive bacteria (63). A variety of stimuli have been observed to induce $\beta$ defensin genes which contain recognition sites for NFkB including bacteria, LPS, TNF, IL-1 and IL-6 (63, 205, 288). Moreover, commensal bacteria itself have been shown to stimulate epithelial surfaces to express antimicrobial peptides at levels that kill pathogen microbes (38). Therefore, intestinal epithelial cells actively participate in host defense and do not simply constitute an inert barriere for this purpose. Defensins are also stored in granules of polymorph mononuclear cells facilitating killing of ingested microorganisms (85). Interestingly, several neutrophil defensins kill grampositive bacteria at concentrations as low as $1 \mu \mathrm{g} / \mathrm{ml}$, whereas higher concentrations are required to kill gramnegative bacteria (267). In contrast, the converse is true for enteric defensins indicating the divergent functional evolution in dependency on the natural environment (209). Since, several defensins have been shown to exhibit chemoattractant properties and particularly to attract both immature dendritic cells (DC) and memory T cells $(86,319)$ it is tempting to speculate that in inflamed mucosa this may contribute to shape innate immune host response as well as sets the stage for the adaptive phase of immune response. Moreover, chemokines itself have been shown to exert potent antimicrobial activity, e.g. against E. coli but also Staphylococcus aureus, Candida albicans and others $(60,86)$.

\section{Physical mucosal barrier}

The most critical barrier between the host and the external environment preventing absorption of intraluminal microbes and microbial products however, is the epithelium per se. Four different types of epithelial cells absorptive enterocytes, goblet cells, enteroendocrine cells and Paneth cells exist. Although consisting of only a single layer of cells arranged into villus and crypt components, the intestinal epithelium must control the access of potential antigens and pathogens. For this purpose epithelial cells are well equipped to face such a pathogen-rich foreing environment. Specialized cell-cell junctional complexes 
allow for selective paracellular permeability (tight junctions: TJ), maintain intercellular adhesion (intermediated junctions and desmosomes) and permit intercellular communication (gap junctions). Paracellular permeability is regulated by the so-called apical junctional complex (AJC) consisting of TJs and subjacent adherens junction (AJ). Major constituents of TJs are three transmembrane proteins, occludin, claudin and junction adhesion molecule that are associated with intracytoplasmic proteins (zonula occludens ZO-1,-2,-3) as well as E-cadherin and catenins. At the apicolateral epithelial surface these TJs maintain a permeability seal restricting paracellular movement of even very small ( 2 kDA)-molekules/ or a molecular size $>11.5 \mathrm{~A}$ preventing therefore e.g. transepithelial movement of bacteria, macromolecules but also LPS, peptidoglycanpolysaccharides etc. Even histological intact rat intestine has been shown to exhibit increased paracellular flux of H-mannitol and/or CrEDTA during stress mediated at least in part via modifications and redistributions of occludin and ZO-1 $(184,259)$.

Major factors known to disrupt mucosal barrier are mucosal acidosis, hypoxia, oxidative stress and ATPdepletion. These conditions are interrelated in most circumstances but, e.g. mucosal acidosis induced deliberately by increasing arterial carbon dioxide tension leads to substantial increases in epithelial permeabiltiy even in the presence of unchanged perfusion and oxygen tension (253). This clearly indicates that acidosis per se promotes barrier dysfunction. Moreover, oxidants such as hydrogen peroxide and superoxide radicals have been shown to disrupt the cytoskeleton and to increase intestinal permeability (309). As for hypoxia the intestinal villus is particularly dependent on sufficient oxygen delivery since the oxygen tension per se is much lower than in arterial blood even under physiological conditions explaining the increased susceptibility for hypoxic injury. Any decrease in intestinal blood flow ultimately aggravates this condition as soon as oxygen consumption becomes supply dependent concomitantly leading also to mucosal acidosis and ATP-depletion. In thermal injury, trauma, hemorrhagic/ cardiogenic or septic shock there is diminished blood flow to the intestinal mucosa. Therefore, ischemia-induced mucosal injury represents a common pathway to different disease processes leading to dysfunction of the gut barrier.

Mucosal atrophy, particularly as consequence of luminal nutrient deprivation has been suggested as well as predisposing factor for BT (308). However, several experimental models of BT could not convincingly demonstrate morphological changes as cause of intestinal hyperpermeability and/or BT (55). Moreover, Sedman et al. also failed to demonstrate a significant difference in villus height of small bowel biopsies between patients with and without BT (265). Finally, in a mixed population of gastroenterological patients the index of villus atrophy was found not to correlate with intestinal permeability (206). Nonetheless, increased intestinal permeability has been demonstrated in patients with burns (163), following cardiopulmonary bypass (241), elective or emergency major vascular surgery (248), hemorrhagic shock (247), jaundice (217), indomethacin (67), parenteral endotoxin (208) as well as in intensive care patients (125). Gut permeability was also found increased in trauma patients however, presenting no difference between patients with or without infection $(216,247)$. Likewise, O'Boyle et al. did not find any significant differences in the incidence of BT in gastroenterologic patients with normal permeability as compared to patients with increased permeability (206). Finally, BT may not occur even in the presence of gross intestinal mucosal permeability abnormalities (91). Therefore, it appears that increased intestinal permeability is a permissive factor for BT but does not prove that BT has occurred. The failure of evidencing a causative direct link between gut barrier dysfunction and infectious complications in humans suggests that increased intestinal permeability and subsequently infective complications are, at least partly, independent phenomena.

\section{Site of translocation}

In the small intestine amplification of surface area is an adaptation to improve digestion and absorption of nutrients however, at first appearance this seems concomitantly to increase the risk of mucosal colonization by potential pathogens and commensals. Nevertheless, the bacterial load of the small intestine remains very low due to predominant secretion of digestive juices und mucus as well as antibiotic peptides at this site. In contrast to the upper gastrointestinal tract towards the ileocecal junction the number of bacteria increases and species of microflora resemble those found in the colon. It has been suggested that the lower part of the gut because of containing a large number of microbes, has a more efficient capacity for the killing of translocating bacteria. Moreover, the colon presents with different permeability characteristics than the small bowel, including higher electrical resistance and less permeability to the passive movement of ions (229). In fact, under the same bacterial concentrations of E. coli loading significantly higher rates of BT from small 
bowel than from large bowel have been observed indicating that the threshold to the onset of BT is markedly lower in the small intestine (153). Therefore, it appears that bacterial overgrowth and alterations in intestinal permeability in the small bowel have greater potential danger to promote BT.

Noteworthy, in endotoxemia gut mucosal injury has been reported to be greater in the ileum and cecum than in the jejunum (74). During intravenous total parenteral nutrition loss of gut barrier function is observed throughout the small bowel and cecum (but not the colon) whereas oral elemental diet increased intestinal permeability only at the ileum (193). In burn injury models isolated gut loops from the jejunum, ileum and proximal colon showed equivalent rates of translocation of ${ }^{14} \mathrm{C}$-marked E. coli (radionuclide counts) (103). However, higher numbers of viable bacteria in MLN were detected (microbiological culture) when E. coli organisms were inoculated into the jejunal loop as compared to the ileal or colonic loop. In accordance with this concept, particularly proximal gut colonization has been evidenced to be associated with increased BT and septic morbidity in surgical intensive care patients $(168$, 177). In experimental cirrhosis however, histological changes were found to be most marked in the cecum (106). In this context, species known to translocate frequently including $E$. coli and enterococci achieve particularly high densities and metabolic activity in the cecum, since $50 \%$ of total bacterial ribosomal RNA in cecal contents corresponds to these species (178). By contrast, these species account for only $7 \%$ of bacterial ribosomal RNA in faecal samples. Moreover, In the cecum (and right colon) fermentation is very intense leading to high production of short-chain fatty acids, an acidic $\mathrm{pH}(5-6)$ and rapid bacterial growth. Finally, the total anaerobe counts are 100 times less in the cecal content as compared to fecal samples (178) what may well contribute to increases in $\mathrm{BT}$ at this site.

\section{Host immunity}

BT into the underlying tissue can normally be detected in animals and humans without harm to most healthy individuals (207), since organisms are usually efficiently removed by phagocytes. For this purpose the mucosal system is shaped by, and specifically responds to, the commensal flora. Moreover, commensal bacteria exert profound immunomodulatory activity on the surrounding intestinal tissue. However, a major key question relates to defence mechanisms integrated to restrict the penetration and spread of commensal bacteria. Essential among the armentarium of defence mechanisms is the mucosal immune system.

Gut-associated-lymphatic-tissue (GALT): The intestinal tract is an active immune organ, containing essentially every type of leucocyte involved in immune response. The antigen-specific local immune system, termed gut-associated lymphatic tissue (GALT) is the largest immunological organ of the body making up 25\% of mucosal cell mass. This may reflect the constant exposure to the vast and diverse bacterial microflora at the mucosal site. In fact, microbial colonisation of the GI tract affects the composition of the GALT. Exposure to luminal microbes expands the number of intraepithelial lymphocytes, germinal centres with Ig-producing cells arise rapidly within follicles and lamina propria and serum concentrations of Ig's increase substantially. In contrast, germ-free animals have reduced numbers of lamina propria or intra-epithelial T cells (124) and these are increased following the restoration of a normal microflora (137). Moreover, exclusion of microbes from the gut results in decreased macrophage chemotaxis, reduced intracellular killing of pathogens. The GALT comprises more than half of the lymphoid cells in the body and hosts numerous plasma cells, macrophages, neutrophils, Paneth cells and specialized M-cells playing a key role in controlling BT. It consists of three distinct populations: Peyer's patches, immunocytes within the lamina propria and interepithelial lymphocytes. However, the precise role of each cell in the different steps of translocation has not been delineated in detail so far.

Macrophages and dendritic cells (DC) located just below the epithelial dome are well positioned to detect microbial entry. DC are present in peyer patches, MLN and cryptopatches, isolated lymphoid follicles and lymphocyte filled villi as well as in the lamina propria and possibly in the epithelium (200). Proposed mechanisms of bacterial sampling by DC are as follows (281): Firstly, DC may open TJ between epithelial cells sending processes into the lumen directly phagocytosing microbes. This has been evidenced to occur without compromising the epithelial barriere function due to expression of major TJ proteins by these DC $(238,239)$. Secondly, following transport of antigens by M cells, being only present in epithelium overlying organized lymphatic tissue, which sample and deliver luminal antigens to the underlying lymphoid tissue (201). Thirdly, more indirect via up-take of antigen-bearing exosomes shed from epithelial cells. Finally, antigenic material interacts with DC in underlying tissue which may occur particularly when epithelial integrity is 


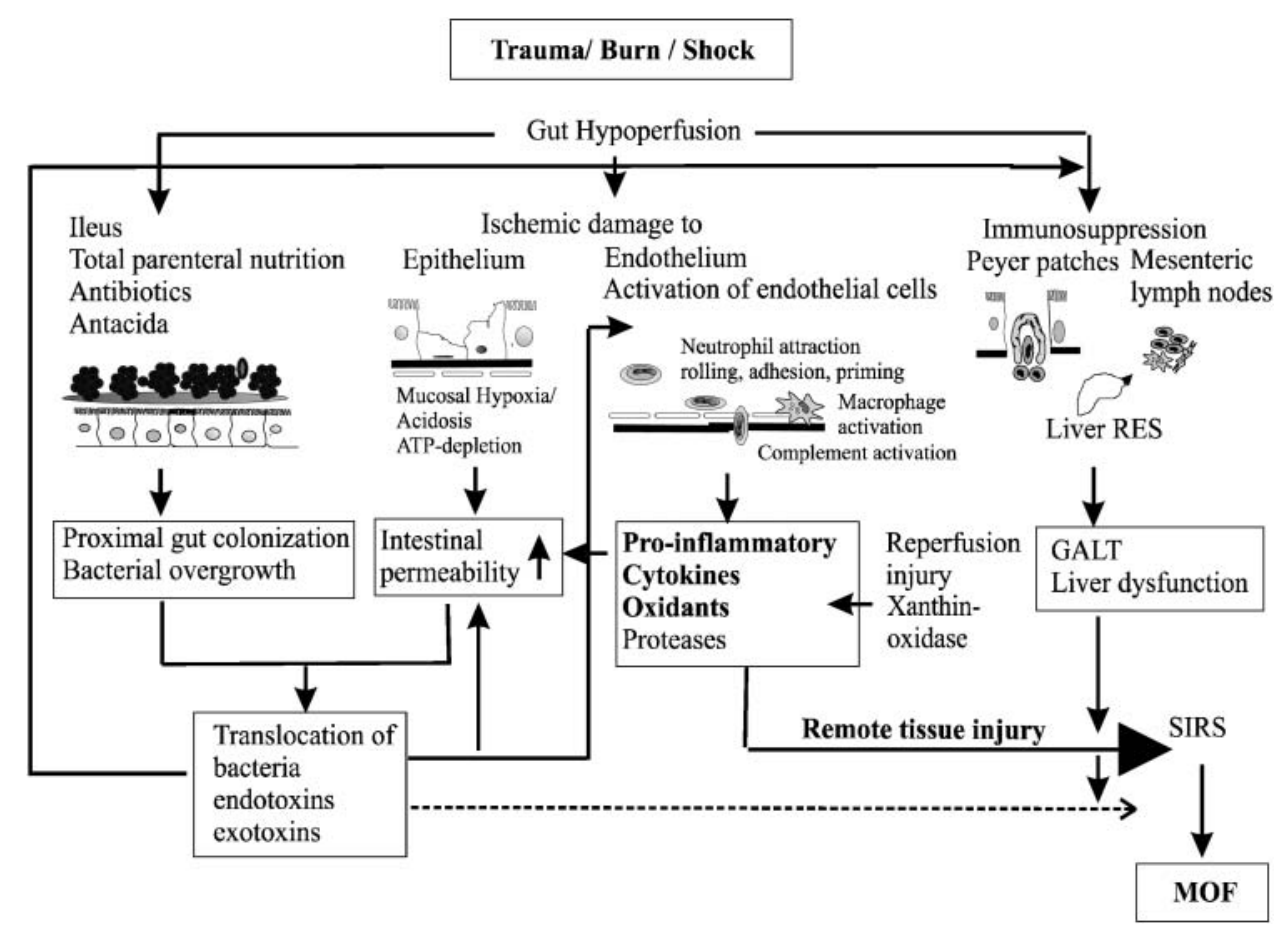

Fig. 2. BT in relation to the pathophysiology of Multiple Organ Failure (MOF). Gut hypoperfusion often leads to bacterial overgrowth via different mechanisms including ileus, standard therapies such as antacida, total parenteral nutrition, antibiotics, morphine etc. Ischemic damage to the epithelium increases mucosal permeability via inadequate intracellular PO2, acidosis and ATP-depletion due to hypoperfusion, anemia, arterial hypoxaemia and/or hypermetabolism secondary to critical illness limiting mitochondrial respiration. Pathophysiological hallmark in the pathogenesis of the SIRS and subsequent MOF is the activation of the endothelium. This may occur via local translocation of bacteria, endo- or exotoxins (that can be limited to the intestinal wall) as well as by subsequent production of oxidants and pro-inflammatory cytokines (e.g. TNF, IL-1). Activation of the endothelium results in attraction, rolling, adherence and transmigration of neutrophils. Adherent neutrophils are primed to produce oxidants, proteases and cytokines resulting in tissue injury. During reperfusion additional oxidants are produced via xanthin oxidase (in endothelial cells and neutrophils). Activation and stimulation of macrophages results in further cytokine release. Thereby, the gut becomes a "cytokine-releasing organ" delivering tissue injury to remote organs. Shock has been shown to depress lymphocytic and macrophage-mediated functional capacities leading to immunosuppression: BT/ endotoxins per se suppress non- and specific immune function: via GALT (stimulation of suppressor T-cells migrating to systemic lymphoid organs), via portal circulation (Kupffer cells: antigen processing and initiation of the specific immune response and tolerance/ insufficiency of non-specific phagocytosis due to overwhelming of the defense capacity), and via systemic circulation (endotoxin-macrophage-lymphocyte interactions causing systemic immunosuppression). Moreover, many anaesthetics can cause immune dysfunction. This immunosuppression contributes essentially to the spreading of bacteria/toxic products and sets the stage for SIRS and MOF to occur.

compromised. Those mechanisms most likely are responsible for the observed engulfment of labeled latex beats or $E$. coli after oral or direct intestinal application and recovery from MLN $(303,305)$. In fact, GALTmacrophages and DC transport the bacteria to MLN initating an adaptive immune response and if the bactericidal activity is impaired to release the microbe/ial products. Mature DC thereby, determine the class of immune response by instructing naïve Th-cells to develop into either effector Th1-, Th2-cells or a mixed phenotype by the selective expression of polarizing molecules (144). Interestinlgly, gram-negative bacteria have been reported to induce expression of Th1polarizing signals in human DC whereas gram-positive bacteria did prime for neither Th1- nor Th-2 development (274). 
The MLN is a central organ in the BT process as well as a major organ in the intestinal immue system. The MLN complex as series of lymph nodes drains lymph from different anatomic regions of the intestine (48). Factors determining trafficing and migration of DC to MLN depend on the state of maturation and source of DC (25). Key regulators of DC migration however, are chemokine-chemokine receptor combinations, especially CCL20/CCR6 for unstimulated lymph DC and CCL21/ CCR7 for mature DC (152). Traffic of DC follows afferent lymph vessels and is directed towards MLN. Indeed intragastrically applied marked Enterobacteriae could be isolated from MLN and were shown to reside in DC (170). Several lines of evidence indicate that MLN confine live commensals within DC to the mucosal immune system and avoid systemic spread and priming by these organisms $(169,170)$. In mice, after surgical removal of MLN and enteral bacterial challenge live bacteria could be cultured from the spleen, whereas bacteria did not penetrate beyond MLN in wild-type mice. (170). Moreover, usually enteric bacteria induced to translocate by oral antibiotics remain confined to the MLN and do not appear to establish a persistent infection in the MLN since, the MLN returns to sterile state when the antibiotic therapy is discontinued and the cecal population of enteric organisms returns to normal levels $(27,30)$. Immunosuppression however, allowed the translocating bacteria to spread systemically and ultimately resulted in lethal sepsis (28). Therefore, it becomes apparent that for BT to become clinically significant a failure of local and/or systemic immune defense must occur.

\section{Mechanisms and immunological aspects}

The reader should not be left with the impression that BT has to be considered always as negative aspect of biology and being linked intellectually to systemic disease unequivocally. BT occurs in the normal host, as evidenced by recovery of viable intestinal bacteria from MLN of a small proportion of healthy animals and humans $(29,42,265)$. Moreover, it is likely that also dead bacteria translocate as a normal biological process. After being sensitized antigen-presenting cells and immature immune cells of the GALT not only leave the intestinal tract (as stated migrating through the thoracic duct and participating in systemic immunity) but also preferentially seed back to the intestinal mucosa as mature $T$ and $B$ cells. In fact, a tissue-and region-specific homing might be more precise, rather than simple traffic to the entire gut. For instance, CCR 9 has been identified as a gut-homing chemokine receptor that marks, essentially, all CD4+ and CD8+ memory or effector T lymphocytes in the small intestine, whereas in the colon only a few cells express CCR 9 (322). Thus, it is conceivable to consider BT as a probably normal and essential process regulating local and systemic immunity and tolerance to the innumerable antigens that contact the intestinal epithelium.

The acquired immune response appears to play a significant role in limiting BT. Owens and Berg noted spontaneous BT of certain indigenous bacteria, such as E. coli, to MLN, spleen and liver in athymic $(\mathrm{nu} / \mathrm{nu})$ mice, whereas no translocation was noted in heterozygous (nu/+) or nude mice grafted with thymus (213). Moreover, T-cell depletion not only caused accumulation of bacteria in MLN in healthy rats but also increased bacterial numbers observed in MLN of alcohol- and burn-injured rats and did cause spreading of bacteria to extraintestinal sites (55). Therefore, it appears that appropriate activation of intestinal $\mathrm{T}$ cells is critical in maintaining immunity against the translocation of enteric bacteria (108). Additional studies showed the ability of adoptively transferred $\mathrm{T}$ cells to confer protection against a number of bacterial infections including $E$. coli (109). Mechanisms by which T cells help maintaining humoral immunity may include T-cell dependent antibody production and production of chemokines/cytokines by which macrophages and neutrophils are recruited and activated. T-cell depletion (Th- and Ts-compartment) is also observed in patients with advanced cirrhosis (5) but its exact contribution to increases in BT is unknown.

Despite increased BT in IgA-deficient mice (169) commensal-related sepsis is not observed in IgAdeficient animals or humans. Interestingly, DC are also involved in direct IgA induction against commensal bacteria in the lamina propria. This has been demonstrated by repeated intragastrical conditioning of mice with Enterobacter cloacae leading to a selective IgA response in-vivo (170). Moreover, in vitro B cells developed an IgA response only when co-cultured with DC that have been pulsed prior by E. cloacae. This anticommensal intestinal secretory IgA-response was induced similarly by LPS, is T-cell-independent and is antigen-driven or in other words does not simply reflect the presence of "natural antibody" but is specificially induced by antigenic changes. Such specific IgA functions to coat commensal bacteria that have escaped DC and then being emenable for rapid up-take by Fc $\alpha / \mu$ bearing phagocytic cells (270). However, the inability of IgA to fix complement efficiently or to act as an opsonin avoids initiation of an inflammatory response (see 
below).

Innate immunity represents the most ancestral and ubiquitious system of defence against microbes/products. Innate immune function is determined by sensing of bacteria/-products, release of chemokines and cytokines leading ultimately to killing of the invader by mononuclear cells. The really crucial importance of phagocytic function of the monocyte/macrophage lineage in the host response when bacteria have penetrated the mucosa and hence, for limiting BT is underscored by several lines of evidence. Since, commensals are usually not pathogenic they have obviously found there "evolutionary niche" without subverting the phagocytic process, presumably because else it would cause inflammation and thereby disrupt the biofilms and filamentous brush border glycocalyx on the epithelium. Therefore, the normally highly functional macrophage bactericidal activity ensures true symbiosis, keeping the commensals right on the edge of the immune system and rapidly eliminating those that have translocated.

Surprisingly, commensal bacteria share abundant molecular patterns used for innate immune recognition of pathogenic bacteria. These highly conserved microbial signature molecules called pathogen-associated molecular patterns (PAMPs) are recognized by most mononuclear cells by so-called pattern recognition receptors (PRRs) (for review see (4). These include the family of toll-like-receptors (TLRs) of which TLR2, 4 and 9 amongst its 11 members are the most relevant ones. The local cellular components of defence against BT (epithelium and GALT-MNC) all express TLR's but do so tightly controlled and predominantly intracellularly/ compartementalized (290) in order to avoid unintended stimulation and mucosal inflammation. In fact, in contrast to pathogenic bacteria commensals normally do not trigger acute inflammation at the epithelium due to its hyporesponsiveness to PAMPs such as LPS. Moreover, efficient killing of commensals penetrating the mucosa normally prevents an inflammatory response. In addition, binding of non-pathogenic bacteria to the epithelium suppresses NFkB-activation by blocking IkB degradation explaining why neutrophils are rarely seen in healthy intestinal mucosa (174). In other words, the intestinal epithelium sets the anti-inflammatory tone of the GALT. However, as soon as inflammation occurs or mucosal LPS load becomes overwhelming DC and other monocytes and neutrophils are recruited the process of BT may become perpetuated $(143,271)$. For instance, migration of neutrophils across epithelial surfaces increase $\mathrm{TJ}$ permeability as do pro-inflammatory cytokines, particularly TNF and INF $\gamma(58)$.

\section{Genetic aspects/polymorphisms}

Whether susceptibility genes for increased BT exist are not yet known. However, several new insights into genetic aspects of mucosal immunity may well point to a "genetic component" in the pathophysiology of BT. For instance, a newly discovered family of proteins, the NBS-LRR proteins (for nucleotide-binding site and leucine-rich repeat) are involved in intracellular recognition of microbes and their products. One such candidate gene mediating increases in microbial invasion and associated inflammation may be the caspaseactivating and recruitment domain-15 (CARD15)/NOD2 gene. The CARD15/NOD2 protein has been described as an intracellular sensor to muramyl dipeptide, a component of the bacterial cell wall, mediating consecutive NF-kB activation (138). Functional studies have shown that NOD2 confers responsiveness to LPS and peptidoglycan and enables sensing of gram-positive and -negative bacteria $(49,138)$. Multiple mutations in CARD15/NOD2 have thus been associated with an impaired activation of NFkB in intestinal epithelial cells but also monocytes and macrophages in response to intestinal bacteria (49). Insufficient activation of NFkB has been suggested then to result in deficient elimination of translocated bacteria. In fact, transfection of epithelial cells with CARD15/NOD2 has been shown to strongly accelerate bacterial clearence (132). Interestingly NOD proteins confer LPS responsiveness independently of TLR4/MD8 8 suggesting that they form a new intracellular LPS signaling axis (114). Moreover, TNF up-regulates NOD2-expression in intestinal epithelial cells via the transcription factor NFkB increasing LPS susceptibility (245). Overall CARD15/NOD2 may initate a gene program aimed at eliminating invasive intracellular bacteria. In deed, polymorphisms in CARD15/NOD2 gene expression have been implicated in the pathogenesis of morbus crohn $(136,210)$ as well as gastrointestinal GvHD and mortality after allogeneic stem cell transplantation (134) all conditions known to be associated with increased BT.

In summary, immunological host defence against BT is subject to regulation at many levels including sensing of microbes/-ial products by PRRs, release of chemokines and cytokines, induction of an adaptive immune response and biosynthetic pathways mediating synthesis and release of antimicrobial peptides and mediators. Moreover, all these pathways are not acting seperately but in a most likely concerted synergistic manner. This complexicity however, blurres the view on alterations of 
Table 1. Human studies on BT (modified after Wiest et al. (311)).

\begin{tabular}{lll}
\hline \multicolumn{1}{c}{ Clinical Condition } & Method testing BT & \multicolumn{1}{c}{ References } \\
\hline Intestinal obstruction/ Ileus & MLN, serosa & $(76,265)$ \\
Crohn's disease & MLN & $(11,159)$ \\
Organ donors & MLN, BC, endotoxin & $(294)$ \\
Elective surgery & MLN & $(265)$ \\
Aortic aneurysm repair & BC & $(317)$ \\
Cardiac surgery & Endotoxin, L/M ratio & $(14,179)$ \\
Burn injury & BC, L/M ratio & $(72,163,313)$ \\
Trauma / Hemorrhagic shock & BC, MLN, endotoxin & $(93,133,191,192,219,247,249)$ \\
Obstructive jaundice & MLN & $(158,217)$ \\
Heart failure & Endotoxin & $(44,45,161,202,227)$ \\
(Hemorrhagic) Pancreatitis & MLN, BC & $(13,24,142,167,197)$ \\
Bowel transplant & BC, stool, liver culture & $(56)$ \\
Liver cirrhosis & MLN, endotoxin, BC & $(57,100,120)$ \\
Malnutrition & L/M ratio & $(308)$ \\
Alcohol & PEG400, endotoxin & $(218)$ \\
Drugs, Chemotherapy & BC, EM & $(10,97,148,189)$ \\
Neutropenia & BC & $(62,286)$ \\
Malignancy & BC & $(286)$ \\
\hline
\end{tabular}

specific pathways and particularly the sequence of events leading to increases in BT. Thus, what seems to be a peaceful coexistence between the host and its beneficial microbial flora in reality reflects a permanent struggle, illustrating the extraordinary effectiveness of the mucosal immune system. Thus, we still need to obtain much better direct data on the mechanisms that each of these stated defence arms is using to contain the commensals largely within the intestinal lumen.

\section{Clinical relevance of bacterial translocation}

The economic burden of BT can be substantial. In the U.S. up to $10 \%$ of hospitalized patients develop nosocomial infections costing more than 4.5 billion $\$$ annually. Although many of these infections are acquired exogenously there is increasing evidence that many infections are caused by translocating enteric bacteria. The incidence of gram-negative bacteremia varies from 70.000 to 330.000 cases per year in the U.S. with an associated persistently high mortality of $20-40 \%$ despite intense efforts in improving therapy.

The first evidence that translocation can occur in humans comes in form of a report by Krause et al. who documented that oral ingestion of a suspension of viable Candida albicans resulted in transient fungaemia and funguria in a normal volunteer (156). Increased BT has been shown to occur in various patient populations ranging from mildly to the critically ill (Table 1). Deitch et al. could isolate viable enteric bacteria from MLN's obtained at laparotomy from patients with small bowel obstruction (76). Similar results were observed by
Ambrose et al. investigating patients undergoing abdominal surgery for Crohn's disease (11). In general, gastrointestinal dysmotility or at its extreme ileus due to functional and/or mechanical intestinal obstruction promotes BT via intestinal dilatation, increased luminal pressure and bacterial overgrowth $(171,203)$. In braindead organ donors with anatomically intact gastrointestinal tract intestinal bacteria could be isolated in $>50 \%$ of cases (294). Sedman et al. studied 267 consecutive general surgery patients and found evidence of BT to MLN's in $10.3 \%$ of patients (265). A comparable rate of BT of $16 \%$ was found in 114 patients in whom operation afforded access of the peritoneal cavity for various reasons (42). Increased incidences of BT were observed again in patients with distal intestinal obstruction $(38.5 \%)$ and in patients with inflammatory bowel disease $(15.8 \%)$. Without these two subgroups overall rate of positive cultures of MLN's was $5 \%$. Woodcock et al. investigated 51 patients undergoing open abdominal aortic aneurysm repair and found enteric bacteria isolated from MLN's in 5/51 patients (10\%). Septic complications occurred significantly more frequent in patients with BT. In fact, one patient in whom E.coli was grown from MLN developed an aortoenteric fistula, with a coliform bacteria isolated from the graft (317). Also cardiac surgery has been evidenced to be accompanied by increases in intestinal permeability and systemic endotoxemia $(14,179,241)$. One of the most established causes of increased BT not only in experimental models but also in humans is thermal injury. Burn patients with $39 \pm 12 \%$ of surface 
area affected were found to present uniformily increased $\mathrm{L} / \mathrm{M}$ ratio indicating increased intestinal permeability (163). Moreover, in burn patients that died more than $50 \%$ had intestinal lesions and more than $80 \%$ were septic mostly with intestinal organisms (79). Finally, after thermal injury increased plasma levels of endotoxin are detectable within 24 hours of the burn with the degree of endotoxemia being closely correlated to the magnitude of injury (313).

In severly injured trauma patients Moore et al. failed to demonstrate bacteria or endotoxin in the portal or systemic blood obtained over the first 5 days of hospitalization even though $60 \%$ of the patients were in shock at the time of presentation (191). Also Peitzman et al. did find only sterile cultures of MLN's obtained at the time of coeliotomy from trauma patients (219). However, Rush et al. as well as Moore et al. found a high incidence of positive blood cultures in severely injured patients with shock in the early phase after traum as compared to those patients without shock. Nonetheless, an exceptionally high proportion of gram-positive organisms was observed $(192,249)$ and most notably, these gram-positive microbes appeared to be of no clinical significance. In contrast, typical enteric bacteremia was detected in few cases, mostly in cases of severe shock and with fatal outcome. Finally, Endo et al. obtained serial blood samples ( 0.5 to 168 hours after arrival) in severly injured patients who arrived in shock and detected elevated LPS levels in only $2 \%$ of specimen (93). Therefore, it appears that BT can be demonstrated only in a small number of trauma patients who are moribund at arrival rendering the clinical importance of $\mathrm{BT}$ in this situation at least doubtful.

However, a number of studies have documented increases in gut permeability and BT in humans challenged with low doses of endotoxin (208) or patients with critical illness of various reasons $(125,246,248)$. It has been claimed that BT may represent a significant source of sepsis in the critically ill patient via intestinally derived bacteria/endotoxin and subsequently induced production and release of pro-inflammatory cytokines (as well as eicosanoids and degranulation products) (71, 276). The hypothesis that the gut can become a cytokinereleasing organ is attractive because it might explain why signs and symptoms of sepsis frequently are present in critically ill patients even in the absence of a well-defined focus of infection. Thus, the gut may compromise a reservoir of triggering compounds that initiate, perpetuate or intensify the systemic inflammatory response, ultimately leading to the development of multiorgan dysfunction/ failure (MOF) (Fig. 2). An increased incidence of septic complications in those patients who had evidence of BT at surgical operation compared with those who did not has been observed first by Brooks et al. and was confirmed by Sedmann et al. and other groups $(42,265,317)$. However, occurrence of BT was not affecting mortality. In addition, it is important to note that in the study by Sedman et al. overall most cases of sepsis occurred in patients without BT. This also brings about attention to the method of detecting BT since, Sedman et al. like most studies evaluating BT in humans did culture only one lymph node at one location. Perhaps if multiple cultures of MLN's had been performed more positive MLN's would have been found in patients in whom sepsis later developed. The mesenteric lymph has been suggested to be an important channel for delivery of a variety of inflammatory mediators from the gut to remote organs $(172,173)$. Toxic products in mesenteric lymph has been demonstrated when none could be identified in the portal or systemic circulation. This route of spreading gut-derived cytokines has been demonstrated to play a key role for development of shock-induced lung injury. Division or ligation of lymphatics in the gut mesentery before induction of shock prevented increases in lung permeability and limited shock-induced pulmonary neutrophil recruitment and lung injury $(70,255)$. Likewise, prevention of gramnegative translocation has been reported to reduce the severity of hepatopulmonary syndrome in chronic-bileduct-ligated rats (233).

Due to the stated effects of bile obstructive jaundice and the associated lack of endoluminal bile in the intestine has been shown to facilitate BT $(59,217,240$, 273) and to enhance susceptibility for further translocation in response to endotoxins (240). In contrast to animal models evidencing increased BT in obstructive jaundice O'Boyle et al. and Sedman et al. however, failed to observe an increase in positive cultures of MLN's in such patients $(207,265)$. Parks et al. nonetheless, demonstrated increased intestinal permeability in patients with obstructive jaundice being normalized after internal biliary drainage (217). Moreover, Kuzu et al. detected BT in $5 / 21$ patients $(24 \%)$ undergoing laparotomy for obstructive jaundice versus $1 / 30(3.5 \%)$ electively operated control patients $(\mathrm{p}<0.05)$ (158). Since, positive lymph node culture was not associated with systemic infection in either group the clinical importance and associated risk remains to be defined.

Poor cardiac function has also been linked to BT. Patients with severe acute heart failure displayed elevated serum endotoxin levels being significantly higher in the hepatic vein as compared to the left 
ventricle indicating translocation from the bowel into the blood stream (227). Also chronic heart failure and recent-onset peripheral edema has been reported to present with significantly elevated serum endotoxin and cytokine concentrations in absence of any signs of active infection (202). Short-term intensive diuretic treatment significantly decreased and almost normalized endotoxin levels indicating that mesenteric venous congestion due to congestive heart failure at least partly may be responsible for the observed increase in translocation of endotoxins. Moreover, in children with congenital heart disease undergoing surgical repair pre-operative endotoxinemia was observed in $40 \%$ of cases being associated with more severe hemodynamic disturbances and elevated mortality postoperatively (161).

The bacterial contamination of pancreatic necrosis in acute pancreatitis has been indicated to occur through translocation of intestinal bacteria (139). However, few studies have evaluated the issue of BT in pancreatitis. Nettelbladt et al. report a patient suffering from hemorrhagic pancreatitis, developing MOF with fatal outcome, in whom the same strain of E. coli was found in feces, blood, MLN's and intraperitoneal fluid suggesting that BT was the pathway of infection (197). Beger et al. already 1986 tested bacteriologically necrotic material obtained at surgery from patients with acute necrotizing pancreatitis. Intestinal microorganisms were cultured in almost $40 \%$ of cases and was associated with more widespread necrosis and significantly elevated mortality (24). A collective latest review of organisms associated with secondary pancreatic infection in patients with acute pancreatitis confirmed that most of them are intestinal flora strongly indicating BT from the gut as source of contaminating bacteria (230). This may well be due to increased intestinal permeability that has been demonstrated in patients with acute pancreatitis being significantly more pronounced in patients with severe pancreatitis (142). However, despite evidencing endotoxemia Ammori et al. failed to detect microbial DNA by PCR-methods in any patient with severe acute pancreatitis suggesting a discrepancy between the significant increase in intestinal permeability and BT (12). Nonetheless, several experimental studies revealed that acute pancreatitis promotes BT, in turn leading to infection of the pancreas and septic complications (129, 140). Interestingly, it has been demonstrated that when pancreatic infection occurs interstitial pancreatitis progresses to necrotizing pancreatitis with the action of nonpancreatic proteolytic encymes, including amidase, produced by bacteria (150).

In small bowel transplantation very traumatic surgery, ischemia/reperfusion injury, prolonged postoperative ileus or rejection predispose to $\mathrm{BT}$. In rats, BT, endotoxemia and bacteremia have been reported to occur within hours of transplantation $(43,231)$. Since, inclusion of the colon to the graft increased fecal bacterial counts, rate of BT and infectious complications the colon is suspected to be the predominant source of translocating organisms $(56,278)$. Few human data are available, but BT has been reported to occur in $44 \%$ of pediatric patients undergoing small bowel transplantation with prolongation of cold ischemia time strongly influencing the rate of BT (56). Unfortunately, no statement on the effect on outcome is made.

In liver cirrhosis BT is thought to be causative for the development of spontaneous infections such as spontaneous bacterial peritonitis (165) but also to be linked to other severe complications such as the hyperdynamic circulatory syndrome (107) a key factor in the growth of varices and in the development of ascites and hepatorenal syndrome. Increased BT in cirrhosis has been attributed to intestinal bacterial overgrowth $(21$, 22 ), increased intestinal permeability (47) as well as a defect in host immunity $(128,318)$. Intestinal bacterial overgrowth has been indicated to be due to small intestinal dysmotility and prolonged intestinal transit time (51) related at least partly to enhanced adrenergic sympathetic nerve activity in cirrhosis (226). As for mucosal barriere dysfunction oxidative damage (237) as well as increased serum levels of nitric oxide and endotoxins (120) both known to disrupt the epithelial barrier may contribute. Moreover, decreased secretory IgA levels have been observed (250) easing bacterial attachment to the mucosa and hence penetration. Finally, host immune response is impaired in liver cirrhosis by decreased reticuloendothelial phagocytic activity, deficiencies in serum immunglobulines, complement and qualitative neutrophil function $(99,234,243,318)$. For instance, cirrhotic patients with lower serum complement (C3 and C4) levels have been considered prone to develop SBP (284). Moreover, impaired tuftsin activity, known to modulate biological activities of phagocytic cells, is reduced in cirrhotic patients and is associated with a higher incidence of bacterial infections (287).

In animal models, starvation and malnutrition as well as total parenteral nutrition (TPN) promotes bacterial overgrowth, diminishes intestinal mucin production, decreases global gut IgA levels, causes mucosal atrophy increasing intestinal permeability, attenuates the $\mathrm{T}$ and $\mathrm{B}$ lymphocyte cell number and function in Peyer Patches and lamina propria and accelerates oxidative stress (9, $75,199)$. Therefore, it appears that lack of enteral 
feeding profoundly affects the cellular and immunological status designed to protect the host from BT. In fact, also in malnourished patients significant increases in intestinal permeability in association with a heightened acute phase response has been evidenced (308). In this context of nutrition, alcohol intake has been associated with deterioration of humoral and cellular components of GALT-function, namely decreased phagocytic function of macrophages (194), decreased natural killer activity (186), reduction in numbers of polymorphnuclear leukocytes, $T$ cells and $B$ cells (301) and attenution of mitochondrial antioxidant glutathion (147) as well as decreases in mucosal IgA transcytosis (82). Therefore, not surprisingly alcohol consumption has been shown to increase intestinal permeability resulting in increased portal levels of endotoxins in animal models and patients with alcoholic liver disease $(35,180,218)$. This indeed may explain why selective gut decontamination almost completely protects animals from liver injury due to alcohol exposure/intake (268).

The association of hematological malignancies with bacterial infections is well-known and is represented by $>50 \%$ of febrile episodes most likely being caused by common enteric residental organisms (36). Moreover, a strong correlation seems to exist between granulocytopenia and bacteraemia caused by Enterobacteriaceae and Pseudomonas. Indeed, characterization of those bacteria by antibiotypic, biotypic and serotypic parameters evidenced concordance with strain isolates from faeces indicating that the blood-borne strains originate from the patients gastrointestinal tract (286). Accordingly, an increase in bowel permeability has been observed after bonemarrow transplantation peaking at 1-2 weeks after transplantation and normalizing by 4 weeks (97). Moreover, divers drugs (e.g. colchicine, cyclosporine) may alter intestinal permeability $(10,189)$. In this respect, particularly chemotherapeutic agents have been shown to impair mucsoal barriere not only in patients with hematological malignancies and bone marrow transplantation but also solid tumors $(97,148)$. In summary, BT may represent a common and so far inadequately recognized trigger for a multitude of complications known for long in various clinical entities.

\section{THERAPY}

Three broad approaches are used to prevent or treat BT which are directed against the three main mechanisms promoting BT and hence are manipulations of the intestinal microflora, protection of the gut mucosa barriere and immunomodulatory efforts.

As for the first, the most attractive and consequent therapy aiming at prevention of BT is selective gut decontamination (SDD). Major targets of SDD performed typically with tobramycin, polymyxin E, amphotericin or cefotoxin are Enterobacter, Pseudomonas, Acetobacter and yeast. The whole issue in respect to its use in the intensive care unit (ICU) treating critical ill patients is still under review. Although several previous large-scale clinical trials failed to demonstrate a significant survival benefit, current meta-analyses challanged that conclusion. An anusual and provocative review of 53 randomized trials and 6 meta-analysis involving more than $8500 \mathrm{ICU}$ patients clearly evidenced significant reductions in the rate of pneumonia and also mortality $(66,196,295)$. In addition a most recent prospective controlled (but unblinded) trial randomized 934 ICU patients to either oral and enteral polymyxin E, tobramycin and amphotericin B combined with an initial 4 day intravenous cefotaxime (as SDD) or to standard therapy. The use of SDD led to a significant reduction in ICU and hospital mortality (68). Particularly colonization with gram-negative bacteria was reduced in SDD patients. Despite these encouraging and valid evidences SDD is used only rarely, in the UK in only $4 \%$ of ICU's. Most likely this reflects the frequently practiced basis of treatment that opinion prevails over evidence, driven additionally by pharmaceutical industry pressure to promote expensive systemic antibiotic use at the time of infection rather than using cheap and effective but difficult to administer prophylactic SDD. Nonetheless, in special entities systemic and/or topical antibiotics are used more frequently such as acute-necrotizing pancreatitis or liver cirrhosis. SDD has been shown to reduce the incidence of secondary pancreatic infection and, in those with a high expected mortality, to improve survival (167). A recent meta-analysis of three randomized-controlled trials comparing antibiotic prophylaxis with no prophylaxis in patients with acutenecrotizing pancreatitis revealed that antibiotic prophylaxis significantly reduced the rate of sepsis and mortality as compared to controls $(196,269)$. Moreover, SDD has been used in patients undergoing liver transplantation and is routinely used in patients undergoing intestine and bone marrow transplantation (92). This is based on the well-known high incidence of serious postoperative bacterial infections and the intensive immunosuppression in those patients. Furthermore, prophylactic usefulness of SDD has been evidenced to decrease the rate of SBP and to improve 
Table 2. Examples of therapeutic approaches in prevention of BT (modified after Wiest et al. (311)).

\begin{tabular}{|c|c|c|}
\hline Therapy & Disease/ Model & References \\
\hline Enteral nutrition & Surgical patients & $(190)$ \\
\hline Immunonutrition/ fiber & Severly injured patients & $(157,280)$ \\
\hline Immunoglobulin A & $\begin{array}{l}\text { Formula-fed neonatal rabbits/ } \\
\text { low-birth-weight infants }\end{array}$ & $(81,83,89)$ \\
\hline Fish-oil & TPN/ Low endotoxin & $(232)$ \\
\hline Prostacyclin/ prostaglandin E & $\begin{array}{l}\text { Low-dose endotoxin in cat } \\
\text { Burn injury in mice }\end{array}$ & $\begin{array}{l}(78) \\
(102)\end{array}$ \\
\hline Ornithine- $\alpha$ ketoglutarate & Endotoxin / Small bowel transplant in rat & $(69,263)$ \\
\hline Lactulose & Obstructive jaundice, portal hypertension, surgery & $(94,214,215)$ \\
\hline Lactobacillus/ probiotics & Liver injury, short bowel, enterocolitis in rat & $(1,90,175)$ \\
\hline Hyperbaric oxygen & Intestinal obstruction, obstructive jaundice, LPS in rat & $(2,3)$ \\
\hline Polymyxin /anti-endotoxin & Septic/ burned patients & $(15,195325)$ \\
\hline \multirow[t]{2}{*}{ BPI } & Endotoxemia/ hemorrhagic shock in rats & $(154,321)$ \\
\hline & Meningococcal sepsis/ trauma patients & $(77,116)$ \\
\hline Neutrophil depletion & Thermal injury in rats & (96) \\
\hline Anti-L-selectin & Hemorrhagic shock in baboons & $(262)$ \\
\hline Xanthine oxidase inhibition & Hemorrhagic/ portal hypertensive rats & $(260)$ \\
\hline C1-inhibitor & Thermal injury in pigs & $(236)$ \\
\hline IL-6 & Hemorrhagic shock in mice & $(244)$ \\
\hline IL-11 & Burn injury mice, leukemia-chemotherapy patients & $(91,261)$ \\
\hline ACE-inhbition (enalapril) & Thermal injury mice & $(110)$ \\
\hline Angiotensin-II-inhibitor DuP753 & Thermal injury / endotoxin in minipigs & $(285)$ \\
\hline Preferential iNOS-inhibition & Thermal injury/ endotoxemia in rat & $(54,289)$ \\
\hline NOX (NO-scavanger) & Endotoxinemia in rat & $(80)$ \\
\hline Cholylsarcosine (conj. bile acid) & Liver cirrhosis, in rat & $(166)$ \\
\hline Glucagon-like peptide 2 & Acute necrot. Pancreatitis in rat & $(155)$ \\
\hline Growth hormone, IGF-1 & $\begin{array}{l}\text { Acute necrotizing pancreatitis, TPN, sepsis, irradiation, } \\
\text { burn injury, etc. }\end{array}$ & $(7,104,135,264,299)$ \\
\hline SDD & $\begin{array}{l}\text { Critical ill, pancreatitis, liver-, bone marrow transplant-, } \\
\text { cirrhotic patients }\end{array}$ & $(31,92,149,167,242,266)$ \\
\hline
\end{tabular}

Note: We apologize that, due to limitation of references being allowed to be cited only examples are given and the list of references is far from being complete.

survival in cirrhotic patients with gastrointestinal hemorrhage known to be at high risk of developing severe bacterial infections (31). Finally, due to the excessive risk of recurrence of SBP secondary prophylaxis is recommended in any cirrhotic patient recovering from an episode of SBP (242). The recommended first choice antibiotics in cirrhotics are quinolones, usually norfloxacin due to its simple administration and low cost.

Another approach to manipulate intestinal microflora is by using probiotics such as lactobacilli. Lactobacilli constitute an integral part of the normal gastrointestinal microecology and may play an important role in the preservation of the natural biological equilibrium of the intestinal tract and the growth modulation of other groups of bacteria (98). The oral administration of lactobacilli induces changes in intestinal environmental factors including increased formation of short chain fatty acids and reduction of colonic $\mathrm{pH}$ which promotes the growth of gram positive and anaerobic bacteria, thereby inhibiting the growth of gram-negative bacteria (105, 141, 252). However, Lactobacilli show many other additional nutritional and protective benefits such as: induction of growth factors (118), maintenance of gastrointestinal epithelial proliferation and function (117), removal of toxins, inhibition of adherence and invasion of enterovirulent bacteria to human intestinal cell lines (32), enhancement of intestinal IgA secretion and host resistance against infection through an increase in global phagocytic activity, as well as the induction of interferon and cytokine production and an increase in killer cells and T lymphocytes $(220-225,275)$. This battery of effects have been shown to inhibit translocation of $E$. coli in an in-vitro human colonic cell culture and to attenuate BT in experimental models of acute liver injury, enterocolitis, short bowel syndrome and others $(1,90,175,182)$. In humans, probiotics have been tested in a number of gastrointestinal diseases and beneficial effects have been evidenced in inflammatory bowel disease, chronic pouchitis and diarrheal diseases, 
particularly in children, postantibiotic as well as clostridial or rotaviral enterocolitis (for review (101)). However, direct evidence for probiotics lowering BT in patients suffering from any of these conditions is lacking.

As for measures to protect the gut mucosa barriere multiple enteral manoeuvres have been tested. Oral supplementation with IgA completely abrogated BT in formula-fed neonatal rabbits by enhancing the gut mucosal barrier (81). Similar results as well as a decrease in translcoation to liver and spleen in neonatal gut-derived sepsis has been observed after enteral IgAsupplementation by Maxson et al. (183). Moreover, feeding a combination of IgA and IgG prevented necrotizing enterocolitis in low-birth-weight infants (89). One of the suggestetd mechanisms by which IgA is mediating these benefits are oligosaccharide receptors for $E$. coli type 1 fimbrial lectin. IgA posesses high mannose type $\mathrm{N}$-linked side chains effectively agglutinating and binding $E$. coli inhibiting its epithelial adherence $(314,315)$. Addition of fiber or glutamine to enteral or parenteral diet, both supposed to be trophic for the mucosa of ileum and colon, has been shown to ameliorate alterations in gut barrier function (280). Results of therapeutic use of glutamine in humans at nonphysiological doses however, indicate limited efficacy and although it is generally recognized to be safe side effects have been reported. Thus, its use in clinical practice is controversial (46). The administration of ornithin-a ketoglutarate $(\mathrm{OKG})$ has also been shown to exert beneficial effects on intestinal structure and to function as well as on cellular immunity. OKG is a salt formed from two molecules of ketoglutarate and one ornithin which are absorbed in the jejunum and after dissociation release glutamate, arginine and proline. OKG- supplemented diet has been demonstrated to limit bacterial dissemination after endotoxin challenge and to reduce BT after small-bowel transplantation in rats $(69$, 263). Modulation of the fatty-acid composition by fishoil-enriched diets has been shown to preserve intestinal blood flow and to enhance host's ability to kill translocated bacteria in various experimental models $(113,232)$. Fish-oil contains precursors of the less inflammatory leukotrienes of the 5-series and favors formation of prostaglandins of the 3 -series which have been reported to reverse endotoxin-induced intestinal vasoconstriction, enhance mucus secretion and downregulate TNF-synthesis (78). Moreover, it has been demonstrated that prostaglandin $\mathrm{E}$ analogues reduce the number of translocating bacteria being associated with improved survival in experimental thermal injury (102).

Several growth-factors (GF) have been shown to be effective in preventing mucosal damage to divers injurious events. Growth hormone is known to exert multiple effects including increases in intestinal absorption of amino acids, promotion of protein synthesis causing hyperplasia of intestinal epithelial cells and to increase the thickness of the mucosal membrane as well as secretory IgA release. In a combined sepsis/ TPN-animal model as well as in irradiated rats prophylactic treatment with growth hormone has been shown to alleviate damage to intestinal barrier function and to reduce BT $(84,292)$. In a rat model of acute necrotizing pancreatits growth hormone reduced the severity of injury in the ileum, improved intestinal mucosal barrier function, decreased endotoxin levels and lowered the incidence of BT and improving survival (299). It has been suggested that growth hormone mediated effects may depend largely on the associated hepatic and gastrointestinal production of insulin-likegrowth-factor-1 (IGF-1). In fact, for instance in radiation enteritis even small doses of IGF-1 could reproduce the effects of growth hormone and in some parameters the effects were more pronounced (7). Similar beneficial effects for growth hormone as well as IGF-1 have been reported in animal models of obstructive jaundice (264), severe burn injury $(104,135)$ and small intestinal transplantation (324). Whether the same holds true in human patients needs to be answered. Other agents awaiting further assessment after individual reports on lowering BT include glucagon-like peptide-2 (GLP-2) $(50,155)$, granulocyte-macrophage colony-stimulating factor (GM-CSF) $(88,111)$, epidermal growth factor (EGF) $(52,185)$, bombesin $(53,127)$, neurotensin $(291)$ or peptide YY.

IL-11 is a multifactorial bone marrow stromal-derived GF whose major effect is proliferation of megakaryocyte progenitor cells, preventing chemotherapy-induced thrombocytopenia. Recombinant IL-11 also protects enterocytes from toxic injury. In an experimental $P$. aeruginosa model, rhIL-11 supported intestinal mucosal integrity, reduced bacteraemia/ endotoxemia and increased survival (211). In a recent double-blind placebo-controlled randomised trial in human leukaemia subjects undergoing chemotherapy rhIL-11 reduced significantly the frequency and load of bacteraemia of gastrointestinal origin and preserved enterocyte integrity (91). RhIL-11, administred orally as enteric-coated multiparticulate pellets, providing local release, is also effective (212). IL-6 orally has likewise been demonstrated to reduce the number of translocating bacteria to MLN, liver and spleen during hemorrhagic shock in mice and to prevent histological changes in the 
intestine induced by hemorrhagic shock (244). In contrast, IL- 6 has been suggested by others to play an essential role in mediating gut mucosal permeability and $\mathrm{BT}$ as a consequence of haemorrhagic shock and resuscitation as demonstrated in IL-6 knock out mice (320). Therefore, its role remains controversial.

Increased infiltration of neutrophils promotes BT and hence, interference with neutrophil function or adhesion decreases mucosal injury. Neutrophil depletion has been shown to reduce $\mathrm{BT}$ in a model of thermal injury in rats (96) and to improve survival time in a hemorrhagictraumatic shock model (262). A recent randomized prospective double-blind and placebo-controlled trial showed that inhibition of leukocyte adherence by administration of monoclonal antibody directed against ICAM-1 improves wound healing without increasing infectious complications indicating the potential use of such an approach $(187,188)$. Moreover, the role of reactive oxygen species derived, for instance from activated neutrophils, is supported by the utility of freeoxygen radical scavengers or inhibitors of xanthine oxidase which increase cellular energy stores, decrease mucosal injury and reduce the incidence of BT in various animal models $(72,73,298)$. In this context, $N O X$, a NO scavanger, also significantly reduced transmucosal passage of bacteria and hence, the incidence of BT and bacteremia after high dose endotoxin challenge in rats (80). This has been attributed to a reduction in peroxynitrite formation known to induce DNA strand breaks, activating the poly(ADP)-ribose synthetase system and causing ATP-depletion.

Finally, approaches aiming at enhancing immunological defense mechanisms against BT have been multiple. Hyperbaric delivery of hyperoxia (HBO2) has been reported to reduce BT in experimental models of intestinal obstruction, burn injury, endotoxemia systemic inflammation and obstructive jaundice $(2,3,112,235$, 251). HBO2 has multiple biochemical and physiological tissue and antibacterial effects including enhancing tissue repair, angiogenesis, optimizing tissue oxygenation, bacteriostasis and enhancing host defenses. For instance, $\mathrm{HBO} 2$ exerts bacteriostatic effects on some strains of E.coli, preventing bacterial overgrowth. Moreover, it increases killing capacity of phagocytes and neutrophils which require molecular oxygen as a substrate for microbial killing. Finally, it has been demonstrated to attenuate mucosal nuclear factor-kB activation and thus, lowering iNOS-derived NO overproduction as well myeloperoxidase activity (251). This dramatic benefit of $\mathrm{HBO} 2$ has been reported to be synergistic with that of IgA in reducing $\mathrm{BT}$ (83). $\mathrm{HBO} 2$ has been used successfully in individual cases of haemorrhagic shock in patients who refused blood on religious grounds (160). However, randomized-controlled trials and hence, clinical evidence for its use in critical illness are yet absent.

The therapeutic use of anti-endotoxin antibodies has been reported to reduce mortality in patients with gramnegative sepsis (325) but these results have been criticized and could not be confirmed (310). However, the use of monoclonal antibody to endotoxin was evidenced to result in greater resolution of organ failure and prevention of adult respiratory distress syndrome in patients with gram-negative sepsis (39). Moreover, the use of endotoxin neutralizing peptides such as polymyxin has been shown to reduce endotoxin levels in burn patients without effect on mortality (195). This lack of effect has been attributed to the fact that although the antibodies bound to endotoxin they did not neutralize its toxic effect completely $(40,300)$. In addition, "immunoparalysis" as compensatory anti-inflammatory response to the systemic appearance of inflammatory mediators may be excessive in some patients causing immunosuppression that hinders the effect of antibodies against endotoxin. A physiological protein with potent anti-endotoxin properties is bactericidal/permeability increasing protein (BPI), found in granulas of neutrophils. BPI binds to, neutralizes and accelerates clearence of LPS, suppresses endotoxin-mediated cellular activation and also exhibits antibacterial properties specifically against gram-negative bacteria. rBPI has been shown to protect against endogenous bacteria or endotoxin-related disorders in experimental models of severe hemorrhagic shock or thermal injury improving survival $(95,321)$. It has likewise been used safely and efficiently in children with meningococcemia $(115,116)$ and has demonstrated a favourable trend in reducing mortality or serious complications in patients with hemorrhage due to trauma (77). These promising results need further validation and confirmation by larger randomized controlled trials.

In summary, despite promising results for treatement and prevention of BT in experimental studies the heterogenous nature of human patients, diversity of clinical endpoints and result interpretation, wide range of perceptions and priorities has hindered the clarity of expert opinion in this arena. The only way to battle these shortcomings is to perform corresponding randomized controlled clinical trials in well-defined patient cohorts evaluating such treatment strategies.

The authors regret that, due to space limitations, it was not possible to cite all of the many contributions by 
investigators who have advanced understanding in this area. Parts of the following manuscript have been published previously in Baillieres Best Clinical Practice North America (311).

\section{REFERENCES}

(1) Adawi D, Kasravi FB, Molin G, Jeppsson B. 1997. Effect of Lactobacillus supplementation with and without arginine on liver damage and bacterial translocation in an acute liver injury model in the rat. Hepatology 25: 642-647.

(2) Akin ML, Erenoglu C, Dal A, Erdemoglu A, Elbuken E, Batkin A. 2001. Hyperbaric oxygen prevents bacterial translocation in rats with obstructive jaundice. Dig Dis Sci 46: 1657-1662.

(3) Akin ML, Uluutku H, Erenoglu C, Ilicak EN, Elbuken E, Erdemoglu A, et al. 2002. Hyperbaric oxygen ameliorates bacterial translocation in rats with mechanical intestinal obstruction. Dis Colon Rectum 45: 967-972.

(4) Akira S, Takeda K, Kaisho T. 2001. Toll-like receptors: critical proteins linking innate and acquired immunity. Nature Immunology 2: 675-680.

(5) Albillos A, de la Hera A, Reyes E, Monserrat J, Munoz L, Nieto M, et al. 2004. Tumor necrosis factor-alpha expression by activated monocytes and altered $\mathrm{T}$-cell homeostasis in ascitic alcoholic cirrhosis: amelioration with norfloxacin. J Hepatol 40: 624-631.

(6) Alexander JW, Boyce ST, Babcock GF, Gianotti L, Peck MD, Dunn DL, et al. 1990. The process of microbial translocation. Ann Surg 212: 496-510.

(7) Alexandrides T, Spiliotis J, Mylonas P, Melachrinou M, Kardamakis D, Spiliopoulou I, et al. 1998. Effects of growth hormone and insulin-like growth factor-I on radiation enteritis. a comparative study. Eur Surg Res 30: $305-311$.

(8) Alverdy J, Holbrook C, Rocha F, Seiden L, Wu RL, Musch M, et al. 2000. Gut-derived sepsis occurs when the right pathogen with the right virulence genes meets the right host: evidence for in vivo virulence expression in Pseudomonas aeruginosa. Ann Surg 232: 480-489.

(9) Alverdy JC, Aoys E, Moss GS. 1988. Total parenteral nutrition promotes bacterial translocation from the gut. Surgery 104: 185-190.

(10) Alzieu M, Fartoux L, Zuber J, Lesage D, Offenstadt G. 1999. [Bacterial translocation in colchicine poisoning]. Presse Med 28: 1420.

(11) Ambrose NS, Johnson M, Burdon DW, Keighley MR. 1984. Incidence of pathogenic bacteria from mesenteric lymph nodes and ileal serosa during Crohn's disease surgery. Br J Surg 71: 623-625.

(12) Ammori BJ, Fitzgerald P, Hawkey P, McMahon MJ. 2003. The early increase in intestinal permeability and systemic endotoxin exposure in patients with severe acute pancreatitis is not associated with systemic bacterial translocation: molecular investigation of microbial DNA in the blood. Pancreas 26: 18-22.

(13) Ammori BJ, Leeder PC, King RF, Barclay GR, Martin IG, Larvin M, et al. 1999. Early increase in intestinal permeability in patients with severe acute pancreatitis: correlation with endotoxemia, organ failure, and mortality. J Gastrointest Surg 3: 252-262.

(14) Andersen LW, Baek L, Degn H, Lehd J, Krasnik M, Rasmussen JP. 1987. Presence of circulating endotoxins during cardiac operations. J Thorac Cardiovasc Surg 93: 115-119.

(15) Angus DC, Birmingham MC, Balk RA, Scannon PJ, Collins D, Kruse JA, et al. 2000. E5 murine monoclonal antiendotoxin antibody in gram-negative sepsis: a randomized controlled trial. E5 Study Investigators. JAMA 283: 1723-1730.

(16) Arai T, Yoshikai Y, Kamiya J, Nagino M, Uesaka K, Yuasa N, et al. 2001. Bilirubin impairs bactericidal activity of neutrophils through an antioxidant mechanism in vitro. J Surg Res 96: 107-113.

(17) Aranow JS, Fink MP. 1996. Determinants of intestinal barrier failure in critical illness. Br J Anaesth 77: 7181.

(18) Ayabe T, Satchell DP, Wilson CL, Parks WC, Selsted ME, Ouellette AJ. 2000. Secretion of microbicidal alpha-defensins by intestinal Paneth cells in response to bacteria. Nat Immunol 1: 113-118.

(19) Banning N, Toze S, Mee BJ. 2002. Escheria coli survival in groundwater and effluent measured using a combination of propidium iodide and the green fluorescent protein. J Appl Microbiol 93: 69-76.

(20) Batt RM, McLean L. 1987. Comparison of the biochemical changes in the jejunal mucosa of dogs with aerobic and anaerobic bacterial overgrowth. Gastroenterol 93: 986-993.

(21) Bauer TM, Schwacha H, Steinbrückner B, Brinkmann FE, Ditzen AK, Aponte JJ, et al. 2002. Small intestinal bacterial overgrowth in human cirrhosis is associated with systemic endotoxemia. Am J Gastroenterol 97: 2364-2370.

(22) Bauer TM, Steinbruckner B, Brinkmann FE, Ditzen AK, Schwacha H, Aponte JJ, et al. 2001. Small intestinal bacterial overgrowth in patients with cirrhosis: prevalence and relation with spontaneous bacterial peritonitis. Am J Gastroenterol 96: 2962 2967.

(23) Beachey EH. 1981. Bacterial adherence: adhesinreceptor interactions mediating the attachment of bacteria to mucosal surface. J Infect Dis 143: 325-345.

(24) Beger HG, Bittner R, Block S, Buchler M. 1986. Bacterial contamination of pancreatic necrosis. A prospective clinical study. Gastroenterology 91: 433438.

(25) Bell SJ, Rigby R, English N, Mann SD, Knight SC, Kamm MA, et al. 2001. Migration and maturation of human colonic dendritic cells. J Immunol 166: 49584967.

(26) Berg RD, Garlington AW. 1979. Translocation of certain indigenous bacteria from the gastrointestinal 
tract to the mesenteric lymph nodes and other organs in a gnotobiotic mouse model. Infect Immun 23: 403411.

(27) Berg RD, Owens WE. 1979. Inhibition of translocation of viable Escherichia coli from the gastrointestinal tract of mice by bacterial antagonism. Infect Immun 25: $820-827$.

(28) Berg RD, Wommack E, Deitch EA. 1988. Immunosuppression and intestinal bacterial overgrowth synergistically promote bacterial translocation. Arch Surg 123: 1359-1364.

(29) Berg RD. 1983. Bacterial translocation from the gastrointestinal tracts of mice receiving immunosuppressive chemotherapeutic agents. Curr Microbiol 8: 285-292.

(30) Berg RD. 1980. Mechanisms confining indigenous bacteria to the gastrointestinal tract. Am J Clin Nutr 33: 2472-2484.

(31) Bernard B, Grange JD, Khac EN, Amiot X, Opolon P, Poynard T. 1999. Antibiotic prophylaxis for the prevention of bacterial infections in cirrhotic patients with gastrointestinal bleeding: a meta-analysis. Hepatology 29: 1655-1661.

(32) Bernet MF, Brassart D, Neeser JR, Servin AL. 1994. Lactobacillus acidophilus LA 1 binds to cultured human intestinal cell lines and inhibits cell attachment and cell invasion by enterovirulent bacteria. Gut 35: 483-489.

(33) Bertok L. 1977. Physico-chemical defense of vertebrate organisms: the role of bile acids in defense against bacterial endotoxins. Perspect Biol Med 21: 70-76.

(34) Bjarnason I, MacPherson A, Hollander D. 1995. Intestinal permeability: an overview. Gastroenterology 108: $1566-1581$.

(35) Bjarnason I, Ward K, Peters T. 1984. The leaky gut of alcoholism: possible route of entry for toxic compounds. Lancet 1: 179-182.

(36) Bodey GP, Rodriguez V, Chang HY, Narboni G. 1978. Fever and infections in leukemic patients: a study in 494 consecutive patients. Cancer 41: 1610-1622.

(37) Boedeker EC. 1994. Adherent bacteria: breaching the mucosal barrier? Gastroenterology 106: 255-257.

(38) Boman HG. 2000. Innate immunity and the normal microflora. Immunol Rev 173: 5-16.

(39) Bone RC, Balk RA, Fein AM, Perl TM, Wenzel RP, Reines HD, et al. 1995. A second large controlled clinical study of E5, a monoclonal antibody to endotoxin: results of a prospective, multicenter, randomized, controlled trial. The E5 Sepsis Study Group. Crit Care Med 23: 994-1006.

(40) Bone RC. 1995. Sepsis clinical trials. Don Quixote revisited. Chest 107: 298-299.

(41) Brook I, MacVittie TJ, Walker RI. 1984. Recovery of aerobic and anaerobic bacteria from irradiated mice. Infect Immun 46: 270-271.

(42) Brooks SG, May J, Sedman P, Tring I, Johnstone D, Mitchell CJ, et al. 1993. Translocation of enteric bacteria in humans. Br J Surg 80: 901-902.

(43) Browne BJ, Johnson CP, Roza AM, Adams MB. 1992. Endotoxemia after small bowel transplantation. Transplant Proc 24: 1107.

(44) Brunkhorst FM, Clark AL, Forycki ZF, Anker SD. 1999. Pyrexia, procalcitonin, immune activation and survival in cardiogenic shock: the potential importance of bacterial translocation. Int J Cardiol 72: 3-10.

(45) Brunkhorst FM. 1999. Endotoxins in chronic heart failure. Lancet 354 (9178): 599-600.

(46) Buchman AL. 2001. Glutamine: commercially essential or conditionally essential? A critical appraisal of the human data. Am J Clin Nutr 74: 25-32.

(47) Campillo B, Pernet P, Bories PN, Richardet JP, Devanlay M, Aussel C. 1999. Intestinal permeability in liver cirrhosis: relationship with severe septic complications. Eur J Gastroenterol Hepatol 11: 755 759.

(48) Carter PB, Collins FM. 1974. The route of enteric infection in normal mice. J Exp Med 139: 1189-1203.

(49) Chamaillard M, Girardin SE, Viala J, Philpott DJ. 2003. Nods, Nalps and Naip: intracellular regulators of bacterial-induced inflammation. Cell Microbiol 5: 581-592.

(50) Chance WT, Sheriff S, McCarter F, Ogle C. 2001. Glucagon-like peptide-2 stimulates gut mucosal growth and immune response in burned rats. J Burn Care Rehabil 22: 136-143.

(51) Chang CS, Chen GH, Lien HC, Yeh HZ. 1998. Small intestine dysmotility and bacterial overgrowth in cirrhotic patients with spontaneous bacterial peritonitis. Hepatology 28: 1187-1190.

(52) Chen D, Wang W, Wang J. 2001. Epidermal growth factor prevents increased permeability and bacterial translocation in rats with acute pancreatitis. Chin Med Sci J 16: 46-48.

(53) Chen LW, Hsu CM, Huang JK, Chen JS, Chen SC. 2000. Effects of bombesin on gut mucosal immunity in rats after thermal injury. J Formos Med Assoc 99: 491498.

(54) Chen LW, Hsu CM, Wang JS, Chen JS, Chen SC. 1998. Specific inhibition of iNOS decreases the intestinal mucosal peroxynitrite level and improves the barrier function after thermal injury. Burns 24: 699705.

(55) Choudhry MA, Fazal N, Goto M, Gamelli RL, Sayeed MM. 2002. Gut-associated lymphoid T cell suppression enhances bacterial translocation in alcohol and burn injury. Am J Physiol Gastrointest Liver Physiol 282: G937-G947.

(56) Cicalese L, Sileri P, Green M, Abu-Elmagd K, Kocoshis S, Reyes J. 2001. Bacterial translocation in clinical intestinal transplantation. Transplantation 71: 1414-1417.

(57) Cirera I, Bauer TM, Navasa M, Vila J, Grande L, Taura P, et al. 2001. Bacterial translocation of enteric organisms in patients with cirrhosis. J Hepatol 34: 3237. 
(58) Clayburgh DR, Shen L, Turner JR. 2004. A porous defense: the lacky epithelial barrier in intestinal disease. Lab Invest 84: 282-291.

(59) Clements WD, Parks R, Erwin P, Halliday MI, Barr J, Rowlands BJ. 1996. Role of the gut in the pathophysiology of extrahepatic biliary obstruction. Gut 39: 587-593.

(60) Cole AM, Ganz T, Liese AM, Burdick MD, Liu L, Strieter RM. 2001. Cutting edge: IFN-inducible ELRCXC chemokines display defensin-like antimicrobial activity. J Immunol 167: 623-627.

(61) Corless CE, Guiver M, Borrow R, Edwards-Jones V, Kaczmarski EB, Fox AJ. 2000. Contamination and sensitivity issues with a real-time universal $16 \mathrm{~S}$ rRNA PCR. J Clin Microbiol 38: 1747-1752.

(62) Cornely OA, Schirmacher P. 2001. Clinical picture: Bacterial translocation in neutropenic sepsis. Lancet 358 (9296): 1842.

(63) Cunliffe RN, Mahida YR. 2004. Expression and regulation of antimicrobial peptides in the gastrointestinal tract. J Leukoc Biol 75: 49-58.

(64) Cunliffe RN, Rose F, Keyte J, Abberley L, Chan WC, Mahida YR. 2001. Human defensin 5 is stored in precursor form in normal Paneth cells and is expressed by some villous epithelial cells and by metaplastic Paneth cells in the colon in inflammatory bowel disease. Gut 48: 176-185.

(65) Cursons RT, Jeyerajah E, Sleigh JW. 1999. The use of polymerase chain reaction to detect septicemia in critically ill patients. Crit Care Med 27: 937-940.

(66) DÀmico R, Pifferi S, Leonetti C, Torri V, Tinazzi A, Liberati A. 1998. Effectiveness of antibiotic prophylaxis in critically ill adult patients: systematic review of randomised controlled trials. BMJ 316 : 1275-1285.

(67) Davies GR, Wilkie ME, Rampton DS. 1993. Effects of metronidazole and misoprostol on indomethacininduced changes in intestinal permeability. Dig Dis Sci 38: $417-425$.

(68) de Jonge E, Schultz MJ, Spanjaard L, Bossuyt PM, Vroom MB, Dankert J, et al. 2003. Effects of selective decontamination of digestive tract on mortality and acquisition of resistant bacteria in intensive care: a randomised controlled trial. Lancet 362 (9389): 1011 1016.

(69) de Oca J, Bettonica C, Cuadrado S, Vallet J, Martin E, Garcia A, et al. 1997. Effect of oral supplementation of ornithine-alpha-ketoglutarate on the intestinal barrier after orthotopic small bowel transplantation. Transplantation 63: 636-639.

(70) Deitch EA, Adams C, Lu Q, Xu DZ. 2001. A time course study of the protective effect of mesenteric lymph duct ligation on hemorrhagic shock-induced pulmonary injury and the toxic effects of lymph from shocked rats on endothelial cell monolayer permeability. Surgery 129: 39-47.

(71) Deitch EA, Berg R. 1987. Bacterial translocation from the gut: a mechanism of infection. J Burn Care Rehabil
8: $475-482$.

(72) Deitch EA, Bridges W, Baker J, Ma JW, Ma L, Grisham MB, et al. 1988. Hemorrhagic shock-induced bacterial translocation is reduced by xanthine oxidase inhibition or inactivation. Surgery 104: 191-198.

(73) Deitch EA, Bridges W, Berg R, Specian RD, Granger DN. 1990. Hemorrhagic shock-induced bacterial translocation: the role of neutrophils and hydroxyl radicals. J Trauma 30: 942-951.

(74) Deitch EA, Taylor M, Grisham M, Ma L, Bridges W, Berg R. 1989. Endotoxin induces bacterial translocation and increases xanthine oxidase activity. $\mathrm{J}$ Trauma 29: 1679-1683.

(75) Deitch EA, Xu D, Naruhn MB, Deitch DC, Lu Q, Marino AA. 1995. Elemental diet and IV-TPNinduced bacterial translocation is associated with loss of intestinal mucosal barrier function against bacteria. Ann Surg 221: 299-307.

(76) Deitch EA. 1989. Simple intestinal obstruction causes bacterial translocation in man. Arch Surg 124: 699701.

(77) Demetriades D, Smith JS, Jacobson LE, Moncure M, Minei J, Nelson BJ, et al. 1999. Bactericidal/ permeability-increasing protein (rBPI21) in patients with hemorrhage due to trauma: results of a multicenter phase II clinical trial. rBPI21 Acute Hemorrhagic Trauma Study Group. J Trauma 46: 667676.

(78) Denlinger LC. 2001. Low-dose prostacyclin reverses endotoxin-induced intestinal vasoconstriction: potential for the prevention of bacterial translocation in early sepsis. Crit Care Med 29: 453-454.

(79) Desai MH, Herndon DN, Rutan RL, Abston S, Linares HA. 1991. Ischemic intestinal complications in patients with burns. Surg Gynecol Obstet 172: $257-$ 261.

(80) Dickinson E, Tuncer R, Nadler E, Boyle P, Alber S, Watkins S, et al. 1999. NOX, a novel nitric oxide scavenger, reduces bacterial translocation in rats after endotoxin challenge. Am J Physiol 277: G1281G1287.

(81) Dickinson EC, Gorga JC, Garrett M, Tuncer R, Boyle P, Watkins SC, et al. 1998. Immunoglobulin A supplementation abrogates bacterial translocation and preserves the architecture of the intestinal epithelium. Surgery 124: 284-290.

(82) Diebel LN, Liberati DM, Dulchavsky SA, Diglio CA, Brown WJ. 2002. Ethanol impairs intestinal barrier defense by modulation of immunoglobulin A transport. Surgery 132: 573-581.

(83) Diebel LN, Liberati DM, Dulchavsky SA, Diglio CA, Brown WJ. 1999. Synergistic effect of hyperoxia and immunoglobulin A on mucosal barrier defense. J Trauma 46: 374-378.

(84) Ding LA, Li JS, Li YS, Liu FN, Tan L. 2004. Prophylactic treatment with growth hormone improves intestinal barrier function and alleviates bacterial translocation in stressed rats. Chin Med J 117: 264-269. 
(85) Duits LA, Ravensbergen B, Rademaker M, Hiemstra PS, Nibbering PH. 2002. Expression of $\beta$-defensins 1 and 2 mRNA by human monoytes, macrophages and dendritic cells. Immunology 106: 517-525.

(86) Durr M, Peschel A. 2002. Chemokines meet defensins: the merging concepts of chemoattractants and antimicrobial peptides in host defense. Infect Immun 70: 6515-6517.

(87) Eaves-Pyles T, Alexander JW. 2001. Comparison of translocation of different types of microorganisms from the intestinal tract of burned mice. Shock 16: 148-152.

(88) Eaves-Pyles T, Alexander JW. 1996. Granulocyte colony-stimulating factor enhances killing of translocated bacteria but does not affect barrier function in a burn mouse model. J Trauma 41: 10131017.

(89) Eibl MM, Wolf HM, Furnkranz H, Rosenkranz A. 1988. Prevention of necrotizing enterocolitis in lowbirth-weight infants by IgA-IgG feeding. N Engl J Med 319: 1-7.

(90) Eizaguirre I, Urkia NG, Asensio AB, Zubillaga I, Zubillaga P, Vidales C, et al. 2002. Probiotic supplementation reduces the risk of bacterial translocation in experimental short bowel syndrome. J Pediatr Surg 37: 699-702.

(91) Ellis M, Zwaan F, Hedstrom U, Poynton $\mathrm{CH}$, Kristensen J, Jumaa P, et al. 2003. Recombinant interleukin-11 and bacterial infection in patients with haematological malignant disease undegoing chemotherapy: a double-blind placebo-controlled randomized trial. Lancet 361: 275-280.

(92) Emre S, Sebastian A, Chodoff L. 1999. Selective decontamination of the digestive tract helps to prevent bacterial infections in the early postoperative period of liver transplant. Mt Sinai J Med 66: 310 313.

(93) Endo S, Inada K, Yamada Y, Takakuwa T, Kasai T, Nakae H, et al. 1994. Plasma endotoxin and cytokine concentrations in patients with hemorrhagic shock. Crit Care Med 22: 949-955.

(94) Erbil Y, Berber E, Ozarmagan S, Seven R, Eminoglu L, Calis A, et al. 1999. The effects of sodium deoxycholate, lactulose and glutamine on bacterial translocation in common bile duct ligated rats. Hepatogastroenterology 46: 2791-2795.

(95) Fang WH, Yao YM, Shi ZG, Yu Y, Wu Y, Lu LR, et al. 2001. Effect of recombinant bactericidal/ permeability-increasing protein on endotoxin translocation and lipopolysaccharide-binding protein/ CD14 expression in rats after thermal injury. Crit Care Med 29: 1452-1459.

(96) Fazal N, Shamim M, Khan SS, Gamelli RL, Sayeed MM. 2000. Neutrophil depletion in rats reduces burninjury induced intestinal bacterial translocation. Crit Care Med 28: 1550-1555.

(97) Fegan C, Poynton CH, Whittaker JA. 1990. The gut mucosal barriere in bone marrow transplantation.
Bone Marrow Transplantation 5: 373-377.

(98) Fernandes CF, Amer MA. 1987. Therapeutic role of dietary lactobacilli and lactobacillic fermented dairy products. FEMS Microbiol Rev 46: 343-356.

(99) Fierer J, Finley F. 1979. Deficient serum bactericidal activity against Escherichia coli in patients with cirrhosis of the liver. J Clin Invest 63: 912-921.

(100) Frances R, Benlloch S, Zapater P, Gonzalez JM, Lozano B, Munoz C, et al. 2004. A sequential study of serum bacterial DNA in patients with advanced cirrhosis and ascites. Hepatolog 39: 484-491.

(101) Fric P. 2002. Probiotics in gastroenterology. Z Gastroenterol 40: 197-201

(102) Fukushima R, Gianotti L, Alexander JW, Pyles T. 1992. The degree of bacterial translocation is a determinant factor for mortality after burn injury and is improved by prostaglandin analogs. Ann Surg 216: 438-444.

(103) Fukushima R, Gianotti L, Alexander JW. 1994. The primary site of bacterial translocation. Arch Surg 129: 53-58.

(104) Fukushima R, Saito H, Inoue T, Fukatsu K, Inaba T, Han I, et al. 1999. Prophylactic treatment with growth hormone and insulin-like growth factor I improve systemic bacterial clearance and survival in a murine model of burn-induced gut-derived sepsis. Burns 25: 425-430.

(105) Fuller R. 1991. Probiotics in human medicine. Gut 32: 439-442.

(106) Garcia-Tsao G, Lee FY, Barden GE, Cartun R, West AB. 1995. Bacterial translocation to mesenteric lymph nodes is increased in cirrhotic rats with ascites. Gastroenterology 108: 1835-1841.

(107) Garcia-Tsao G, Wiest R. 2004. Gut microflora in the pathogenesis of the complications of cirrhosis. Best Pract Res Clin Gastroenterol 18: 353-372.

(108) Gautreaux MD, Deitch EA, Berg RD. 1994. T lymphocytes in host defense against bacterial translocation from the gastrointestinal tract. Infect Immun 62: 2874-2884.

(109) Gautreaux MD, Gelder FB, Deitch EA, Berg RD. 1995. Adoptive transfer of T lymphocytes to T-celldepleted mice inhibits Escherichia coli translocation from the gastrointestinal tract. Infect Immun $\mathbf{6 3}$ : 3827-3834.

(110) Gennari R, Alexander JW, Boyce ST, Lilly N, Babcock GF, Cornaggia M. 1996. Effects of the angiotensin converting enzyme inhibitor enalapril on bacterial translocation after thermal injury and bacterial challenge. Shock 6: 95-100.

(111) Gennari R, Alexander JW, Gianotti L, Eaves-Pyles T, Hartmann S. 1994. Granulocyte macrophage colonystimulating factor improves survival in two models of gut-derived sepsis by improving gut barrier function and modulating bacterial clearance. Ann Surg 220: 68-76.

(112) Gennari R, Alexander JW. 1996. Effects of hyperoxia on bacterial translocation and mortality during gut- 
derived sepsis. Arch Surg 131: 57-62.

(113) Gianotti L, Alexander JW, Eaves-Pyles T. 1996. Dietary fatty acids modulate host bacteriocidal response, microbial translocation and survival following blood transfusion and thermal injury. Cliln Nutr 15: 291-296.

(114) Girardin SE, Sansonetti PJ, Philpott DJ. 2002. Intracellular vs. extracellular recognition of pathogens-common concepts in mammals and flies. Trends Microbiol 10: 193-199.

(115) Giroir BP, Quint PA, Barton P, Kirsch EA, Kitchen L, Goldstein B, et al. 1997. Preliminary evaluation of recombinant amino-terminal fragment of human bactericidal/permeability-increasing protein in children with severe meningococcal sepsis. Lancet 350 (9089): 1439-1443.

(116) Giroir BP, Scannon PJ, Levin M. 2001. Bactericidal/ permeability-increasing protein-lessons learned from the phase III, randomized, clinical trial of rBPI21 for adjunctive treatment of children with severe meningococcemia. Crit Care Med 29: S130S135.

(117) Goodlad RA, Wright NA. 1990. Changes in intestinal cell proliferation, absorptive capacity and structure in young, adult and old rats. J Anat 173: 109-118.

(118) Gorbach SL. 1990. Lactic acid bacteria and human health. Ann Med 22: 37-41.

(119) Greer LF, III, Szalay AA. 2002. Imaging of light emission from the expression of luciferases in living cells and organisms: a review. Luminescence 17: 4374.

(120) Guarner C, Soriano G, Tomas A, Bulbena O, Novella MT, Balanzo J, et al. 1993. Increased serum nitrite and nitrate levels in patients with cirrhosis: relationship to endotoxemia. Hepatology 18: 11391143.

(121) Gulney DG. 1997. Regulation of bacterial virulence gene expression by the host environment. J Clin Invest 99: 565-569.

(122) Guo W, Ding J, Huang Q, Jerrells T, Deitch EA. 1995. Alterations in intestinal bacterial flora modulate the systemic cytokine response to hemorrhagic shock. Am J Physiol 269: G827-G832.

(123) Guo W, Magnotti LJ, Ding J, Huang Q, Xu D, Deitch EA. 2002. Influence of gut microflora on mesenteric lymph cytokine production in rats with hemorrhagic shock. J Trauma 52: 1178-1185.

(124) Guy-Grand D, Griscelli C, Vassalli P. 1978. Nature, origin, and traffic in mice in normal and graft-versushost conditions. J Exp Med 148: 1661-1677.

(125) Harris CE, Griffiths RD, Freestone N, Billington D, Atherton ST, Macmillan RR. 1992. Intestinal permeability in the critically ill. Intensive Care Med 18: $38-41$.

(126) Harwig SS, Tan L, Qu XD, Cho Y, Eisenhauer PB, Lehrer RI. 1995. Bactericidal properties of murine intestinal phopholipase A2. J Clin Invest 95: 603610.
(127) Haskel Y, Xu D, Lu Q, Deitch EA. 1994. Bombesin protects against bacterial translocation induced by three commercially available liquid enteral diets: a prospective, randomized, multigroup trial. Crit Care Med 22: 108-113.

(128) Hassner A, Kletter Y, Jedvab M, Aronson M, Shibolet S. 1979. Impaired monocyte function in liver cirrhosis. Lancet 1 (8111): 329-330.

(129) Hayashi J, Kawarda Y, Isaji S, Yokoi H, Higashiguchi T. 1996. Therapeutic effects of continuous intraarterial antibiotic infusion in preventing pancreatic infection in experimental acute necrotizing pancreatitis. Pancreas 13: 184-192.

(130) Heininger A, Binder M, Ellinger A, Pfisterer J, Botzenhart K, Unertl K, et al. 2004. Effect of comprehensive validation of the template isolation procedure on the reliability of bacteraemia detection by a $16 \mathrm{~S}$ rRNA gene PCR. Clin Microbiol Infect 10: 452-458.

(131) Herbst F. 1844. Das Lymphgefäßsystem und seine Verrichtungen. p. 333-337.

(132) Hisamatsu T, Suzuki M, Reinecker HC, Nadeau WJ, McCormick BA, Podolsky DK. 2003. CARD15/ NOD2 functions as an antibacterial factor in human intestinal epithelial cells. Gastroenterol 124: $993-$ 1000 .

(133) Hoch RC, Rodriguez R, Manning T, Bishop M, Mead P, Shoemaker WC, et al. 1993. Effects of accidental trauma on cytokine and endotoxin production. Crit Care Med 21: 839-845.

(134) Holler E, Rogler G, Herfarth H, Brenmoehl J, Wild PJ, Hahn J, et al. 2004. Both donor and recipient NOD2/CARD15 mutations associate with transplantrelated mortality and GvHD following allogeneic stem cell transplantation. Blood 104: 889-894.

(135) Huang KF, Chung DH, Herndon DN. 1993. Insulinlike growth factor 1 (IGF-1) reduces gut atrophy and bacterial translocation after severe burn injury. Arch Surg 128: 47-53.

(136) Hugot JP, Chamaillard M, Zouali H, Lesage S, Cezard JP, Belaiche J. 2001. Association of NOD2 leucine-rich repeat variants with susceptibility to Crohn's disease. Nature 411: 599-603.

(137) Imaoka A, Matsumoto S, Setoyama H, Okada Y, Umesaki Y. 1996. Proliferative recruitment of intestinal intraepithelial lymphocytes after microbial colonization of germ-free mice. Eur J Immunol 26: 945-948.

(138) Inohara N, Ogura Y, Fontalba A. 2003. Host recognition of bacterial muramyl dipeptide mediated through NOD2. Implications for Crohn's disease. J Biol Chem 278: 5509-5512.

(139) Isaji S, Mizuno S, Tabata M, Yamagiwa K, Yokoi H, Uemoto S. 2003. Bacterial analysis of infected pancreatic necrosis and its prevention (Symposium 8: Pancreatobiliary infection (IHPBA)). J Hepatobiliary Pancreat Surg 10: 419-424.

(140) Isaji S, Suzuki M, Frey CF, Ruebner B, Carlson J. 
1992. Role of bacterial infection in diet-induced acute pancreatitis in mice. Int J Pancreatol. 11: 49-57.

(141) Johansson ML, Molin G, Jeppsson B, Nobaek S, Ahrne S, Bengmark S. 1993. Administration of different Lactobacillus strains in fermented oatmeal soup: in vivo colonization of human intestinal mucosa and effect on the indigenous flora. Appl Environ Microbiol 59: 15-20.

(142) Juvonen PO, Alhava EM, Takala JA. 2000. Gut permeability in patients with acute pancreatitis. Scand J Gastroenterol 35: 1314-1318.

(143) Kalff JC, Schwarz NT, Walgenbach KJ, Schraut WH, Bauer AJ. 1998. Leukocytes of the intestinal muscularis: their phenotype and isolation. J Leukoc Biol 63: 683-691.

(144) Kaliniski P, Hilkens CM, Wierenga EA, Kapsenberg ML. 1999. T cell priming by type-1 and type-2 polarized dendritic cells: the concept of a third signal. Immunol Today 20: 561-567.

(145) Kane TD, Johnson SR, Alexander JW, Babcock GF, Ogle CK. 1996. Detection of intestinal bacterial translocation using PCR. J Surg Res 63: 59-63.

(146) Katouli M, Bark T, Ljungqvist O, Svenberg T, Mollby R. 1994. Composition and diversity of intestinal coliform flora influence bacterial translocation in rats after hemorrhagic stress. Infect Immun 62: 4768-4774.

(147) Kaur M, Kaur J, Ojha S, Mahmood A. 1998. Ethanol effects on lipid peroxidation and glutathionemediated defense in rat small intestine: role of dietary fats. Alcohol 15: 65-69.

(148) Keefe DM, Brealey J, Goland GJ, Cummins AG. 2000. Chemotherapy for cancer causes apoptosis that precedes hypoplasia in crypts of the small intestine in humans. Gut 47: 632-637.

(149) Kerver AJ, Rommes JH, Mevissen-Verhage EA, Hulstaert PF, Vos A, Verhoef J, et al. 1988. Prevention of colonization and infection in critically ill patients: a prospective randomized study. Crit Care Med 16: 1087-1093.

(150) Keynes WM. 1980. A nonpancreatic source of the proteolytic-enzyme amidase and bacteriology in experimental acute pancreatitis. Annn Surg 191: 187199.

(151) Klaschik S, Lehmann LE, Raadts A, Hoeft A, Stuber F. 2002. Comparison of different decontamination methods for reagents to detect low concentrations of bacterial $16 \mathrm{~S}$ DNA by real-time-PCR. Mol Biotechnol 22: 231-242.

(152) Kobayashi H, Miura S, Nagata H, Tsuzuki Y, Hokari $\mathrm{R}$, Ogino $\mathrm{T}$, et al. 2004. In situ demonstration of dendritic cell migration from rat intestine to mesenteric lymph nodes: relationships to maturation and role of chemokines. J Leukoc Biol 75: 434-442.

(153) Koh IH, Guatelli R, Montero EF, Keller R, Silva MH, Goldenberg S, et al. 1996. Where is the site of bacterial translocation-small or large bowel? Transplant Proc 28: 2661.
(154) Kohn FR, Ammons WS, Horwitz A, Grinna L, Theofan G, Weickmann J, et al. 1993. Protective effect of a recombinant amino-terminal fragment of bactericidal/permeability-increasing protein in experimental endotoxemia. J Infect Dis 168: 1307 1310.

(155) Kouris GJ, Liu Q, Rossi H, Djuricin G, Gattuso P, Nathan C, et al. 2001. The effect of glucagon-like peptide 2 on intestinal permeability and bacterial translocation in acute necrotizing pancreatitis. Am J Surg 181: 571-575.

(156) Krause W, Matheis H, Wulf K. 1969. Fungaemia and funguria after oral administration of Candida albicans. Lancet 1 (7595): 598-599.

(157) Kudsk KA, Minard G, Croce MA, Brown RO, Lowrey TS, Pritchard FE, et al. 1996. A randomized trial of isonitrogenous enteral diets after severe trauma. An immune-enhancing diet reduces septic complications. Ann Surg 224: 531-540.

(158) Kuzu MA, Kale IT, Col C, Tekeli A, Tanik A, Koksoy C. 1999. Obstructive jaundice promotes bacterial translocation in humans. Hepatogastroenterology 46: 2159-2164.

(159) Laffineur G, Lescut D, Vincent P, Quandalle P, Wurtz A, Colombel JF. 1992. [Bacterial translocation in Crohn disease]. Gastroenterol Clin Biol 16: $777-$ 781.

(160) Leach RM, Rees PJ, Wilmshurst P. 1998. Hyperbaric oxygen therapy. BMJ 317 (7166): 1140-1143.

(161) Lequier LL, Nikaidoh H, Leonard SR, Bokovoy JL, White ML, Scannon P, et al. 2000. Preoperative and postoperative endotoxinemia in children with congenital heart disease. Chest 117: 1706-1712.

(162) Levi AC, Borghi F, Petrino R, Bargoni A, Fronticelli CM, Gentelini S. 1991. Modifications of the trophism of intestinal mucosa after intestinal and biliopancreatic diversion in the rat. Ital J Gastroenterol 23: 202-207.

(163) LeVoyer T, Cioffi WG, Jr., Pratt L, Shippee R, McManus WF, Mason AD, Jr., et al. 1992. Alterations in intestinal permeability after thermal injury. Arch Surg 127: 26-29.

(164) Ljungdahl M, Lundholm M, Katouli M, Rasmussen I, Engstrand L, Haglund U. 2000. Bacterial translocation in experimental shock is dependent on the strains in the intestinal flora. Scand J Gastroenterol 35: 389-397.

(165) Llovet JM, Bartoli R, Planas R, Cabre E, Jimenez M, Urban A, et al. 1994. Bacterial translocation in cirrhotic rats: its role in the development of spontaneous bacterial peritonitis. Gut 35: 1648-1652.

(166) Lorenzo-Zuniga V, Bartoli R, Planas R, Hofmann A, Vinado B, Hagey LR, et al. 2002. Conjugated bile acid ingestion reduces endotoxemia and bacterial translocation in ascitic cirrhotic rats. Gastroenterology, A.

(167) Luiten EJ, Hop WC, Lange JF, Bruining HA. 1995. Controlled clinical trial of selective decontamination 
for the treatment of severe acute pancreatitis. Ann Surg 222: 57-65.

(168) MacFie J, O’Boyle C, Mitchell CJ, Buckley PM, Johnstone D, Sudworth P. 1999. Gut origin of sepsis: a prospective study investigating associations between bacterial translocation, gastric microflora, and septic morbidity. Gut 45: 223-228.

(169) MacPherson A, Gatto D, Sainsbury E, Harriman GR, Hengartner H, Zinkernagel RM. 2000. A primitive T cell-independent mechanism of intestinal mucosal IgA responses to commensal bacteria. Science 288: 2222-2226.

(170) Macpherson AJ, Uhr T. 2004. Induction of protective IgA by intestinal dendritic cells carrying commensal bacteria. Science 303 (5664): 1662-1665.

(171) Madl C, Druml W. 2003. Gastrointestinal disorders of the critically ill. Systemic consequences of ileus. Best Pract Res Clin Gastroenterol 17: 445-456.

(172) Magnotti LJ, Upperman JS, Xu DZ, Lu Q, Deitch EA. 1998. Gut-derived mesenteric lymph but not portal blood increases endothelial cell permeability and promotes lung injury after hemorrhagic shock. Ann Surg 228: 518-527.

(173) Magnotti LJ, Xu DZ, Lu Q, Deitch EA. 1999. Gutderived mesenteric lymph: a link between burn and lung injury. Arch Surg 134: 1333-1340.

(174) Mahida YR, Johal S. 2001. NF-kB may determine whether epithelial cell-microbial interactions in the intestine are hostile or friendly. Clin Exp Immunol 123: 347-349.

(175) Mao Y, Nobaek S, Kasravi B, Adawi D, Stenram U, Molin G, et al. 1996. The effects of Lactobacillus strains and oat fiber on methotrexate-induced enterocolitis in rats. Gastroenterology 111: 334-344.

(176) March JC, Rao G, Bentley WE. 2003. Biotechnological applications of green fluorescent protein. Appl Microbiol Biotechnol 62: 303-315.

(177) Marshall JC, Christou NV, Horn R, Meakins JL. 1988. The microbiology of multiple organ failure. The proximal gastrointestinal tract as an occult reservoir of pathogens. Arch Surg 123: 309-315.

(178) Marteau P, Pochart P, Dore J, Bera-Maillet C, Bernalier A, Corthier G. 2001. Comparative study of bacterial groups within the human cecal and fecal microbiota. Appl Environ Microbiol 67: 4939-4942.

(179) Martinez-Pellus AE, Merino P, Bru M, Conejero R, Seller G, Munoz C, et al. 1993. Can selective digestive decontamination avoid the endotoxemia and cytokine activation promoted by cardiopulmonary bypass? Crit Care Med 21: 1684-1691.

(180) Mason CM, Dobard E, Kolls J, Nelson S. 1998. Effect of alcohol on bacterial translocation in rats. Alcohol Clin Exp Res 22: 1640-1645.

(181) Mason DY, Taylor CR. 1975. The distribution of muramidase (lysozyme) in human tissue. J Clin Pathol 28: 124-132.

(182) Mattar AF, Drongowski RA, Coran AG, Harmon CM. 2001. Effect of probiotics on enterocyte bacterial translocation in vitro. Pediatr Surg Int 17: 265-268.

(183) Maxson RT, Jackson RJ, Smith SD. 1995. The protective role of enteral IgA supplementation in neonatal gut origin sepsis. J Pediatr Surg 30: 231233.

(184) Mazzon E, Sturniolo GC, Puzzolo D, Frisina N, Fries W. 2002. Effect of stress on the paracellular barrier in rat ileum. Gut 51: 507-513.

(185) McAndrew HF, Lloyd DA, Rintala R, van Saene HK. 2000. The effects of intravenous epidermal growth factor on bacterial translocation and central venous catheter infection in the rat total parenteral nutrition model. Pediatr Surg Int 16: 169-173.

(186) Meadows GG, Blank SE, Duncan DD. 1989. Influence of ethanol consumption on natural killer cell activity in mice. Alcohol Clin Exp Res 13: 476479 .

(187) Mileski WJ, Hunt J, Kagan RJ. 1998. Clinical effects of inhibiting leukocyte adhesion with monoclonal antibody to ICAM-1 in the treatment of partial thickness burn injury. Proc Am Burn Assoc 19: S146.

(188) Mileski WJ, Rothlien R, Lipsky P. 1994. Interference with the function of leukocyte adhesion molecules by monoclonal antibodies: a new approach to burn injury. Eur J Pediatr Surg 4: 225-230.

(189) Montero EF, Silva RM, Keller R, Neto AB, Pessuto JM, Kim HC, et al. 1996. Role of cyclosporin A in bacterial translocation. Transplant Proc 28: 2676.

(190) Moore FA, Feliciano DV, Andrassy RJ, McArdle AH, Booth FV, Morgenstein-Wagner TB, et al. 1992. Early enteral feeding, compared with parenteral, reduces postoperative septic complications. The results of a meta-analysis. Ann Surg 216: 172-183.

(191) Moore FA, Moore EE, Poggetti R, McAnena OJ, Peterson VM, Abernathy CM, et al. 1991. Gut bacterial translocation via the portal vein: a clinical perspective with major torso trauma. J Trauma 31: 629-636.

(192) Moore FA, Moore EE, Poggetti RS, Read RA. 1992. Postinjury shock and early bacteremia. A lethal combination. Arch Surg 127: 893-897.

(193) Mosenthal AC, Xu D, Deitch EA. 2002. Elemental and intravenous total parenteral nutrition diet-induced gut barrier failure is intestinal site specific and can be prevented by feeding nonfermentable fiber. Crit Care Med 30: 396-402.

(194) Mufti SI, Prabhala R, Moriguchi S, Sipes IG, Watson RR. 1988. Functional and numerical alterations induced by ethanol in the cellular immune system. Immunopharmacology 15: 85-93.

(195) Munster AM, Smith-Meek M, Dickerson C, Winchurch RA. 1993. Translocation. Incidental phenomenon or true pathology? Ann Surg 218: 321326.

(196) Nathens AB, Marshall JC. 1999. Selective decontamination of the digestive tract in surgical patients. Arch Surg 134: 170-176.

(197) Nettelbladt CG, Katouli M, Bark T, Svenberg T, 
Mollby R, Ljungqvist O. 2000. Evidence of bacterial translocation in fatal hemorrhagic pancreatitis. $\mathrm{J}$ Trauma 48: 314-315.

(198) Nettelbladt CG, Katouli M, Bark T, Svenberg T, Mollby R, Ljungqvist O. 2003. Orally inoculated Escherichia coli strains colonize the gut and increase bacterial translocation after stress in rats. Shock 20: 251-256.

(199) Nettelbladt CG, Katouli M, Volpe A, Bark T, Muratov V, Svenberg T, et al. 1997. Starvation increases the number of coliform bacteria in the caecum and induces bacterial adherence to caecal epithelium in rats. Eur J Surg 163: 135-142.

(200) Neutra MR, Pringault E, Kraehenbuhl JP. 1996. Antigen sampling across epithelial barriers and induction of mucosal immune response. Annu Rev Immunol 14: 275-300.

(201) Neutra MR. 1998. Current concepts in mucosal immunity V. Role of $\mathrm{M}$ cells in transepithelial transport of antigens and pathogens to the mucosal immune system. Am J Physiol 274: G785-G791.

(202) Niebauer J, Volk HD, Kemp M, Dominguez M, Schumann RR, Rauchhaus M, et al. 1999. Endotoxin and immune activation in chronic heart failure: a prospective cohort study. Lancet 353 (9167): 18381842.

(203) Nieuwenhuijs VB, Verheem A, Duijvenbode-Beumer H, Visser MR, Verhoef J, Gooszen HG, et al. 1998. The role of interdigestive small bowel motility in the regulation of gut microflora, bacterial overgrowth, and bacterial translocation in rats. Ann Surg 228: 188-193.

(204) Nikkari S, McLaughlin IJ, Dodge DE, Relman DA. 2001. Does blood of healthy subjects contain bacterial ribosomal DNA. J. Clin. Microbiol 39: 1950-1956.

(205) O’Neil DA, Porter E, Elewaut D, Anderson GM, Eckmann L, Ganz T, et al. 1999. Expression and regulation of the human beta-defensins hBD-1 and hBD-2 in intestinal epithelium. J Immunol 163: 6718-6724.

(206) O'Boyle CJ, MacFie J, Dave K, Sagar PS, Poon P, Mitchell CJ. 1998. Alterations in intestinal barrier function do not predispose to translocation of enteric bacteria in gastroenterologic patients. Nutrition 14: $358-362$.

(207) O’Boyle CJ, MacFie J, Mitchell CJ, Johnstone D, Sagar PM, Sedman PC. 1998. Microbiology of bacterial translocation in humans. Gut 42: 29-35.

(208) O'Dwyer ST, Michie HR, Ziegler TR, Revhaug A, Smith RJ, Wilmore DW. 1988. A single dose of endotoxin increases intestinal permeability in healthy humans. Arch Surg 123: 1459-1464.

(209) Ogle CK, Noel JG, Guo X, Wells DA, Valente JF, Ogle JD, et al. 2002. The ability of endotoxinstimulated enterocytes to produce bactericidal factors. Crit Care Med 30: 428-434.

(210) Ogura Y, Bonen DK, Inohara N, Nicolae DL, Chen
FF. 2001. A frameshift mutation in NOD2 associated with susceptibility to Crohn's disease. Nature 411: 603-606.

(211) Opal SM, Jhung JW, Keith JC, Goldman SJ, Palardy JE, Parejo NA. 1998. Recombinant human interleukin 11 in experimental pseudomonas aeruginosa sepsis in immunocompromised animals. J Infect Dis 178: 1205-1208.

(212) Opal SM, Keith JC, Jhung JW, Palardy JE, Parejo NA, Marchese E, et al. 2003. Orally administred recombinant human IL-11 is protective in experimental neutropenic sepsis. J Inf Dis 187: 70 76.

(213) Owens WE, Berg RD. 1980. Bacterial translocation from the gastrointestinal tract of athymic $(\mathrm{nu} / \mathrm{nu})$ mice. Infect Immun 27: 461-467.

(214) Ozaslan C, Turkcapar AG, Kesenci M, Karayalcin K, Yerdel MA, Bengisun S, et al. 1997. Effect of lactulose on bacterial translocation. Eur J Surg 163: 463-467.

(215) Ozcelik MF, Eroglu C, Pekmezci S, Ozturk R, Paksoy M, Negizade M, et al. 1996. The role of lactulose in the prevention of bacterial translocation in surgical trauma. Acta Chir Belg 96: 44-48.

(216) Pape HC, Dwenger A, Regel G, Auf'm'Kolck M, Gollub F, Wisner D, et al. 1994. Increased gut permeability after multiple trauma. Br J Surg 81: 850-852.

(217) Parks RW, Clements WD, Smye MG, Pope C, Rowlands BJ, Diamond T. 1996. Intestinal barrier dysfunction in clinical and experimental obstructive jaundice and its reversal by internal biliary drainage. Br J Surg 83: 1345-1349.

(218) Parlesak A, Schafer C, Schutz T, Bode JC, Bode C. 2000. Increased intestinal permeability to macromolecules and endotoxemia in patients with chronic alcohol abuse in different stages of alcoholinduced liver disease. J Hepatol 32: 742-747.

(219) Peitzman AB, Udekwu AO, Ochoa J, Smith S. 1991. Bacterial translocation in trauma patients. J Trauma 31: 1083-1086.

(220) Perdigon G, Alvarez S, Pesce de Ruiz Holgado A. 1991. Immunoadjuvant activity of oral Lactobacillus casei: influence of dose on the secretory immune response and protective capacity in intestinal infections. J Dairy Res 58: 485-496.

(221) Perdigon G, Alvarez S, Rachid M, Aguero G, Gobbato N. 1995. Immune system stimulation by probiotics. J Dairy Sci 78: 1597-1606.

(222) Perdigon G, de Macias ME, Alvarez S, Oliver G, de Ruiz Holgado AA. 1986. Effect of perorally administered lactobacilli on macrophage activation in mice. Infect Immun 53: 404-410.

(223) Perdigon G, de Macias ME, Alvarez S, Oliver G, de Ruiz Holgado AP. 1988. Systemic augmentation of the immune response in mice by feeding fermented milks with Lactobacillus casei and Lactobacillus acidophilus. Immunology 63: 17-23. 
(224) Perdigon G, Nader de Macias ME, Alvarez S, Oliver G, Pesce de Ruiz Holgado AA. 1990. Prevention of gastrointestinal infection using immunobiological methods with milk fermented with Lactobacillus casei and Lactobacillus acidophilus. J Dairy Res 57: 255-264.

(225) Perdigon G, Rachid M, De Budeguer MV, Valdez JC. 1994. Effect of yogurt feeding on the small and large intestine associated lymphoid cells in mice. J Dairy Res 61: 553-562.

(226) Perez-Paramo M, Munoz J, Albillos A, Freile I, Portero F, Santos M, et al. 2000. Effect of propranolol on the factors promoting bacterial translocation in cirrhotic rats with ascites. Hepatology 31: 43-48.

(227) Peschel T, Schonauer M, Thiele H, Anker SD, Schuler G, Niebauer J. 2003. Invasive assessment of bacterial endotoxin and inflammatory cytokines in patients with acute heart failure. Eur J Heart Fail 5: 609-614.

(228) Porter E, Van Dam E, Valore EV, Ganz T. 1997. Broad-spectrum antimicrobial activity of human intestinal defensin 5. Infect Immun 65: 2396-2401.

(229) Powell DW. 1981. Barrier function of epithelia. Am J Physiol 241: G275-G288.

(230) Powell JJ, Miles R, Siriwardena AK. 1998. Antibiotic prophylaxis in the initial managment of severe acute pancreatitis. Br J Surg 85: 582-587.

(231) Price BA, Cumberland NS, Clark CL, Pockley AG, Lear PA, Wood RF. 1993. The effect of rejection and graft-versus-host disease on small intestinal microflora and bacterial translocation after rat small bowel transplantation. Transplantation 56: 10721076.

(232) Pscheidl E, Schywalsky M, Tschaikowsky K, BokeProls T. 2000. Fish oil-supplemented parenteral diets normalize splanchnic blood flow and improve killing of translocated bacteria in a low-dose endotoxin rat model. Crit Care Med 28: 1489-1496.

(233) Rabiller A, Nunes H, Lebrec D, Tazi KA, Wartski M, Dulmet E, et al. 2002. Prevention of gram-negative translocation reduces the severity of hepatopulmonary syndrome. Am J Respir Crit Care Med 166: 514-517.

(234) Rabinovitz M, Gavaler JS, Kumar S, Kajani M, Van Thiel DH. 1989. Role of serum complement, immunoglobulins, and cell-mediated immune system in the pathogenesis of spontaneous bacterial peritonitis (SBP). Dig Dis Sci 34: 1547-1552.

(235) Rachmilewitz D, Karmeli F, Okon E. 1998. Hyperbaric oxygen: a novel modality to ameliorate experimental colitis. Gut 43: 512-518.

(236) Radke A, Mottaghy K, Goldmann C, Khorram-Sefat R, Kovacs B, Janssen A, et al. 2000. C1 inhibitor prevents capillary leakage after thermal trauma. Crit Care Med 28: 3224-3232.

(237) Ramachandran A, Prabhu R, Thomas S, Reddy JB, Pulimood A, Balasubramanian KA. 2002. Intestinal mucosal alterations in experimental cirrhosis in the rat: role of oxygen free radicals. Hepatology 35: 622 629.

(238) Rescigno M, Rotta G, Valzasina B, RicciardiCastagnoli P. 2001. Dendritic cells shuttle microbes across gut epithelial monolayers. Immunobiology 204: 572-581.

(239) Rescigno M, Urbano M, Valzasina B, Francolini M, Rotta G, Bonasio R, et al. 2001. Dendritic cells express tight junction proteins and penetrate gut epithelial monolayers to sample bacteria. Nat Immunol 2: 361-367.

(240) Reynolds JV, Murchan P, Leonard N, Clarke P, Keane FB, Tanner WA. 1996. Gut barrier failure in experimental obstructive jaundice. J Surg Res 62: 1116.

(241) Riddington DW, Venkatesh B, Boivin CM, Bonser RS, Elliott TS, Marshall T, et al. 1996. Intestinal permeability, gastric intramucosal $\mathrm{pH}$, and systemic endotoxemia in patients undergoing cardiopulmonary bypass. JAMA 275: 1007-1012.

(242) Rimola A, Garcia-Tsao G, Navasa M, Piddock LJ, Planas R, Bernard B, et al. 2000. Diagnosis, treatment and prophylaxis of spontaneous bacterial peritonitis: a consensus document. J Hepatol 32: 142-153.

(243) Rimola A, Soto R, Bory F, Arroyo V, Piera C, Rodes J. 1984. Reticuloendothelial system phagocytic activity in cirrhosis and its relation to bacterial infections and prognosis. Hepatology 4: 53-58.

(244) Rollwagen FM, Li YY, Pacheco ND, Nielsen TB. 1996. Systemic bacteraemia following haemorrhagic shock in mice: alleviation with oral Interleukin 6 . Cytokine 8: 121-129.

(245) Rosenstiel P, Fantini M, Bräutigam K, Kühbacher T, Waetzig GH, Seegert D, et al. 2003. TNF-a and IFN$y$ regulate the expression of the NOD2 (CARD15) gene in human intestinal epithelial cells. Gastroenterol 124: 1001-1009.

(246) Roumen RM, Frieling JT, van Tits HW, van der Vliet JA, Goris RJ. 1993. Endotoxemia after major vascular operations. J Vasc Surg 18: 853-857.

(247) Roumen RM, Hendriks T, Wevers RA, Goris JA. 1993. Intestinal permeability after severe trauma and hemorrhagic shock is increased without relation to septic complications. Arch Surg 128: 453-457.

(248) Roumen RM, van der Vliet JA, Wevers RA, Goris RJ. 1993. Intestinal permeability is increased after major vascular surgery. J Vasc Surg 17: 734-737.

(249) Rush BF, Jr., Sori AJ, Murphy TF, Smith S, Flanagan JJ, Jr., Machiedo GW. 1988. Endotoxemia and bacteremia during hemorrhagic shock. The link between trauma and sepsis? Ann Surg 207: 549-554.

(250) Saitoh O, Sugi K, Kojima K, Matsumoto H, Nakagawa K, Kayazawa M, et al. 1999. Increased prevalence of intestinal inflammation in patients with liver cirrhosis. World J Gastroenterol 5: 391-396.

(251) Sakoda M, Ueno S, Kihara K, Arikawa K, Dogomori H, Nuruki K, et al. 2004. A potential role of hyperbaric oxygen exposure through intestinal 
nuclear factor-kappaB. Crit Care Med 32: $1722-$ 1729.

(252) Salminen S, Salminen E. 1997. Lactulose, lactic acid bacteria, intestinal microecology and mucosal protection. Scand J Gastroenterol 222: 45-48.

(253) Salzman AL, Wang H, Wollert PS, Vandermeer TJ, Compton CC, Denenberg AG, et al. 1994. Endotoxininduced ileal mucosal hyperpermeability in pigs: role of tissue acidosis. Am J Physiol 266: G633-G646.

(254) Salzman NH, Ghosh D, Huttner KM, Paterson Y, Bevins CL. 2003. Protection against enteric salmonellosis in transgenic mice expressing human intestinal defensin. Nature 422: 522-526.

(255) Sambol JT, Xu DZ, Adams CA, Magnotti LJ, Deitch EA. 2000. Mesenteric lymph duct ligation provides long term protection against hemorrhagic shockinduced lung injury. Shock 14: 416-419.

(256) Samel S, Keese M, Kleczka M, Lanig S, Gretz N, Hafner M, et al. 2002. Microscopy of bacterial translocation during small bowel obstruction and ischemia in vivo - a new animal model. BMC Surg 2: 6.

(257) Sano T, Ajiki T, Takeyama Y, Kuroda Y. 2004. Internal biliary drainage improves decreased number of gut mucosal T lymphocytes and MAdCAM-1 expression in jaundiced rats. Surgery 136: 693-699.

(258) Satterwhite TK, Evans DG, DuPont HL, Evans DJ, Jr. 1978. Role of Escherichia coli colonisation factor antigen in acute diarrhoea. Lancet 2 (8082): 181-184.

(259) Saunders PR, Kosecka U, McKay DM. 1994. Acute stressors stimulate ion secretion and increase epithelial permeability in rat intestine. Am J Physiol 267: G794-G799.

(260) Schimpl G, Pesendorfer P, Steinwender G, Feierl G, Ratschek M, Hollwarth ME. 1996. Allopurinol reduces bacterial translocation, intestinal mucosal lipid peroxidation, and neutrophil-derived myeloperoxidase activity in chronic portal hypertensive and common bile duct-ligated growing rats. Pediatr Res 40: 422-428.

(261) Schindel D, Maze R, Liu Q, Williams D, Grosfeld J. 1997. Interleukin-11 improves survival and reduces bacterial translocation and bone marrow suppression in burned mice. J Pediatr Surg 32: 312-315.

(262) Schlag G, Redl HR, Till GO, Davies J, Martin U, Dumont L. 1999. Anti-L-selectin antibody treatment of hemorrhagic-traumatic shock in baboons. Crit Care Med 27: 1900-1907.

(263) Schlegel L, Coudray-Lucas C, Barbut F, Le Boucher J, Jardel A, Zarrabian S, et al. 2000. Bacterial dissemination and metabolic changes in rats induced by endotoxemia following intestinal E. coli overgrowth are reduced by ornithine alphaketoglutarate administration. J Nutr 130: 2897-2902.

(264) Scopa CD, Koureleas S, Tsamandas AC, Spiliopoulou I, Alexandrides T, Filos KS, et al. 2000. Beneficial effects of growth hormone and insulin-like growth factor I on intestinal bacterial translocation, endotoxemia, and apoptosis in experimentally jaundiced rats. J Am Coll Surg 190: 423-431.

(265) Sedman PC, MacFie J, Sagar P, Mitchell CJ, May J, Mancey-Jones B, et al. 1994. The prevalence of gut translocation in humans [see comments]. Gastroenterology 107: 643-649.

(266) Selective Decontamination Collaborative Group. 1993. Meta-analysis of randomised controlled trials of selective decontamination of the digestive tract. $\mathrm{Br}$ Med J 307: 525-532.

(267) Selsted ME, Szklarek D, Lehrer RI. 1984. Purification and antibacterial activity of antimicrobial peptides of rabbit granulocytes. Infect Immun 45: 154.

(268) Sermon F, Le Moine O, Gustot T, Quertinmont E, Louis H, Nagy N, et al. 2003. Chronic alcohol exposure sensitizes mice to galactosamine-induced liver injury through enhanced keratinocyte chemoattractant and defective IL-10 production. J Hepatol 39: 68-76.

(269) Sharma VK, Howden CW. 2001. Prophylactic antibiotic administration reduces sepsis and mortality in acute necrotizing pancreatitis: a meta-analysis. Pancreas 22: 28-31.

(270) Shibuya A, Sakamato N. 2000. Fca/ $\mu$ receptor mediates endocytosis of IgM-coated microbes. Nature Immunology 1: 441-446.

(271) Shimizu T, Tani T, Hanasawa K, Endo Y, Kodama M. 2001. The role of bacterial translocation on neutrophil activation during hemorrhagic shock in rats. Shock 16: 59-63.

(272) Sleigh J, Cursons R, La Pine M. 2001. Detection of bacteraemia in critically ill patients using $16 \mathrm{~S}$ rDNA polymerase chain reaction and DNA sequencing. Intensive Care Med 27: 1269-1273.

(273) Slocum MM, Sittig KM, Specian RD, Deitch EA. 1992. Absence of intestinal bile promotes bacterial translocation. Am Surg 58: 305-310.

(274) Smits HH, van Beelen AJ, Hessle C, Westland R, de Jong E, Soeteman E, et al. 2004. Commensal Gramnegative bacteria prime human dendritic cells for enhanced IL-23 and IL-27 expression and enhanced Th1 development. Eur J Immunol 34: 1371-1380.

(275) Solis-Pereyra B, Aattouri N, Lemonnier D. 1997. Role of food in the stimulation of cytokine production. Am J Clin Nutr 66: 521S-525S

(276) Sori AJ, Rush BF, Jr., Lysz TW, Smith S, Machiedo GW. 1988. The gut as source of sepsis after hemorrhagic shock. Am J Surg 155: 187-192.

(277) Southward CM, Surette MG. 2002. The dynamic microbe: green fluorescent protein brings bacteria to light. Mol Microbiol 45: 1191-1196.

(278) Spada M, Alessiani M, Fabbi M, Magnino S, Gelmetti D, Vaccarisi S, et al. 1996. Bacterial translocation is enhanced in pig intestinal transplantation when the colon is included in the graft. Transplant Proc 28: 2658-2659.

(279) Spaeth G, Gottwald T, Specian RD, Mainous MR, 
Berg RD, Deitch EA. 1994. Secretory immunoglobulin A, intestinal mucin, and mucosal permeability in nutritionally induced bacterial translocation in rats. Ann Surg 220: 798-808.

(280) Spaeth G, Specian RD, Berg RD, Deitch EA. 1990. Bulk prevents bacterial translocation induced by the oral administration of total parenteral nutrition solution. JPEN J Parenter Enteral Nutr 14: 442-447.

(281) Stagg AJ, Hart AL, Knight SC, Kamm MA. 2003. The dendritic cell: its role in intestinal inflammation and relationship with gut bacteria. Gut 52: 1522 1529.

(282) Steffen EK, Berg RD, Deitch EA. 1988. Comparison of translocation rates of various indigenous bacteria from the gastrointestinal tract to the mesenteric lymph node. J Infect Dis 157: 1032-1038.

(283) Steffen EK, Berg RD. 1983. Relationship between cecal population levels of indigenous bacteria and translocation to the mesenteric lymph nodes. Infect Immun 39: 1252-1259.

(284) Such J, Guarner C, Enriquez J, Rodriguez JL, Seres I, Vilardell F. 1988. Low C3 in cirrhotic ascites predisposes to spontaneous bacterial peritonitis. J Hepatol 6: 80-84.

(285) Tadros T, Traber DL, Heggers JP, Herndon DN. 2000. Angiotensin II inhibitor DuP753 attenuates burn- and endotoxin-induced gut ischemia, lipid peroxidation, mucosal permeability, and bacterial translocation. Ann Surg 231: 566-576.

(286) Tancrede CH, Andremont AO. 1985. Bacterial translocation and gram-negative bacteremia in patients with hematological malignancies. J Infect Dis 152: 99-103.

(287) Trevisani F, Castelli E, Foschi FG, Parazza M, Loggi E, Bertelli M, et al. 2002. Impaired tuftsin activity in cirrhosis: relationship with splenic function and clinical outcome. Gut 50: 707-712.

(288) Tsutsumi-Ishii Y, Nagaoka I. 2002. NF-kB-mediated transcriptional regulation of human beta-defensin-2 gene following lipopolysaccharide stimulation. J Leukoc Biol 71: 154-162.

(289) Unno N, Wang H, Menconi MJ, Tytgat SH, Larkin V, Smith M, et al. 1997. Inhibition of inducible nitric oxide synthase ameliorates endotoxin-induced gut mucosal barrier dysfunction in rats. Gastroenterology 113: $1246-1257$.

(290) Uronen-Hansson H, Allen J, Osman M, Squires G, Klein N, Callard RE. 2004. Toll-like receptor 2 (TLR2) and TLR4 are present inside human dendritic cells, associated with microtubules and the Golgi apparatus but are not detectable on the cell surface: integrity of microtubules is required for interleukin12 production in response to internalized bacteria. Immunology 111: 173-178.

(291) Vagianos C, Karatzas T, Scopa CD, Panagopoulos C, Tsoni I, Spiliopoulou I, et al. 1992. Neurotensin reduces microbial translocation and improves intestinal mucosa integrity after abdominal radiation.
Eur Surg Res 24: 77-83.

(292) Vagianos C, Scopa CD, Panagopoulos C, Pitsis A, Alexandridis T, Kalfarentzos F. 1992. Growth hormone improves intestinal mucosa integrity and reduces bacterial translocation to MLN in irradiated rats. Surg Res Comm 12: 213-220.

(293) Van Bossuyt H, Desmaretz C, Gaeta GB, Wisse E. 1990. The role of bile acids in the development of endotoxemia during obstructive jaundice in the rat. $\mathrm{J}$ Hepatol 10: 274-279.

(294) van Goor H, Rosman C, Grond J, Kooi K, Wubbels GH, Bleichrodt RP. 1994. Translocation of bacteria and endotoxin in organ donors. Arch Surg 129: 1063 1066.

(295) van Saene HK, Petros AJ, Ramsay G, Baxby D. 2003. All great truths are iconoclastic: selective decontamination of the digestive tract moves from heresy to level 1 truth. Int Care Med 29: 677-690.

(296) Vernon SD, Shukla SK, Conradt J, Unger ER, Reeves WC. 2002. Analysis of 16S rRNA gene sequences and circulating cell-free DNA from plasma of chronic fatigue syndrome and non-fatigued subjects. BMC Microbiol 2: 39.

(297) Volkheimer G, Schulz FH. 1968. The phenomenon of persorption. Digestion 1: 213-218.

(298) von Ritter C, Sekizuka E, Grisham MB, Granger DN. 1988. The chemotactic peptide N-formyl methionylleucyl-phenylalanine increases mucosal permeability in the distal ileum of the rat. Gastroenterology 95: 651-656.

(299) Wang X, Wang B, Wu J, Wang G. 2001. Beneficial effects of growth hormone on bacterial translocation during the course of acute necrotizing pancreatitis in rats. Pancreas 23: 148-156.

(300) Warren HS, Danner RL, Munford RS. 1992. Antiendotoxin monoclonal antibodies. N Engl J Med 326: 1153-1157.

(301) Watzl B, Watson RR. 1992. Role of alcohol abuse in nutritional immunosuppression. J Nutr 122: 733-737.

(302) Wells CL, Jechorek RP, Erlandsen SL. 1995. Inhibitory effect of bile on bacterial invasion of enterocytes: possible mechanism for increased translocation associated with obstructive jaundice. Crit Care Med 23: 301-307.

(303) Wells CL, Maddaus MA, Erlandsen SL, Simmons RL. 1988. Evidence for the phagocytic transport of intestinal particles in dogs and rats. Infect Immun 56: 278-282.

(304) Wells CL, Maddaus MA, Reynolds CM, Jechorek RP, Simmons RL. 1987. Role of anaerobic flora in the translocation of aerobic and facultatively anaerobic intestinal bacteria. Infect Immun 55: 2689-2694.

(305) Wells CL, Maddaus MA, Simmons RL. 1987. Role of the macrophage in the translocation of intestinal bacteria. Arch Surg 122: 48-53.

(306) Wells CL. 1996. Colonization and translocation of intestinal bacterial flora. Transplant Proc 28: 2653 2656. 
(307) Wells CL. 1990. Relationship between intestinal microecology and the translocation of intestinal bacteria. Antonie Van Leeuwenhoek 58: 87-93.

(308) Welsh FK, Farmery SM, MacLennan K, Sheridan MB, Barclay GR, Guillou PJ, et al. 1998. Gut barrier function in malnourished patients. Gut 42: 396-401.

(309) Welsh MJ, Shasby DM, Husted RM. 1985. Oxidants increase paracellular permeability in a cultured epithelial cell line. J Clin Invest 76: 1155-1168.

(310) Wenzel RP. 1992. Anti-endotoxin monoclonal antibodies_-a second look. N Engl J Med 326: 11511153.

(311) Wiest R, Rath HC. 2003. Bacterial translocation in the gut. Best Pract Res Clin Gastroenterol 17: 397425.

(312) Wilson CL, Quellette AJ, Satchell DP, Ayabe T, Lopez-Boado YS, Stratman J, et al. 1999. Regulation of intestinal a-defensin activation by the metalloproteinase matrilysin in innate host defense. Science 286: 113-117.

(313) Winchurch RA, Thupari JN, Munster AM. 1987. Endotoxemia in burn patients: levels of circulating endotoxins are related to burn size. Surgery 102: 808812.

(314) Wold AE, Mestecky J, Tomana M, Kobata A, Ohbayashi H, Endo T, et al. 1990. Secretory immunoglobulin A carries oligosaccharide receptors for Escherichia coli type 1 fimbrial lectin. Infect Immun 58: 3073-3077.

(315) Wold AE, Motas C, Svanborg C, Hanson LA, Mestecky J. 1995. Characterization of IgA1, IgA2 and secretory IgA carbohydrate chains using plant lectins. Adv Exp Med Biol 371A: 585-589.

(316) Wong WM, Poulsom R, Wright NA. 1999. Trefoil peptides. Gut 44: 890-895.

(317) Woodcock NP, Sudheer V, El Barghouti N, Perry EP, MacFie J. 2000. Bacterial translocation in patients undergoing abdominal aortic aneurysm repair. Br J Surg 87: 439-442.

(318) Wyke RJ. 1987. Problems of bacterial infection in patients with liver disease. Gut 28: 623-641.

(319) Yang D, Chertov O, Bykovskaia SN, Chen Q, Buffo MJ, Shogan J, et al. 1999. Beta-defensins: linking innate and adaptive immunity through dendritic and T cell CCR6. Science 286: 525-528.

(320) Yang R, Han X, Uchiyama T, Watkins SK, Yaguchi A, Delude RL, et al. 2003. IL-6 is essential for development of gut barrier dysfunction after hemorrhagic shock and resuscitation in mice. Am J Physiol Gastrointest Liver Physiol 285: G621-G629.

(321) Yao YM, Bahrami S, Leichtfried G, Redl H, Schlag G. 1995. Pathogenesis of hemorrhage-induced bacteria/endotoxin translocation in rats. Effects of recombinant bactericidal/permeability-increasing protein. Ann Surg 221: 398-405.

(322) Zabel BA. 1999. Human G protein-coupled receptor GPR-9-6/CC chemokine receptor 9 is selectively expressed on intestinal homing $\mathrm{T}$ lymphocytes, mucosal lymphocytes and thymocytes and is required for thymus-expressed chemokine-mediated chemotaxis. J Exp Med 190: 1241-1256.

(323) Zasloff M. 2002. Antimicrobial peptides of multicellular organisms. Nature 415: 389-395.

(324) Zhang W, Frankel WL, Adamson WT, Roth JA, Mantell MP, Bain A, et al. 1995. Insulin-like growth factor-I improves mucosal structure and function in transplanted rat small intestine. Transplantation 59: 755-761.

(325) Ziegler EJ, Fisher CJ, Jr., Sprung CL, Straube RC, Sadoff JC, Foulke GE, et al. 1991. Treatment of gram-negative bacteremia and septic shock with HA1A human monoclonal antibody against endotoxin. A randomized, double-blind, placebo-controlled trial. The HA-1A Sepsis Study Group. N Engl J Med 324: 429-436.

(326) Zoetendal EG, Collier CT, Koike S, Mackie RI, Gaskins HR. 2004. Molecular ecological analysis of the gastrointestinal microbiota: a review. J Nutr 134: 465-472.

(327) Zoetendal EG, von Wright A, Vilpponen-Salmela T, Ben Amor K, Akkermans AD, de Vos WM. 2002. Mucosa-associated bacteria in the human gastrointestinal tract are uniformly distributed along the colon and differ from the community recovered from feces. Appl Environ Microbiol 68: 3401-3407. 